بررسى نقش گياهان دارويى در ايجاد عوارض سوء كليوى: مطالعهاى مرورى

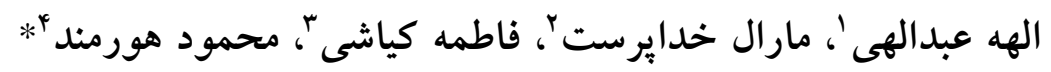 \\ ا- دانشجوى دكتراى تخصصى فارماكولوزى، دانشكده بزشكى، دانشخاه علوم يزشكى ايران، تهران، ايران

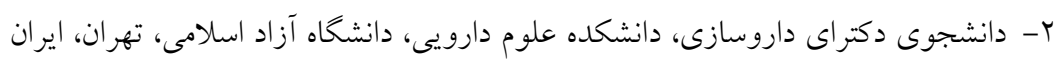

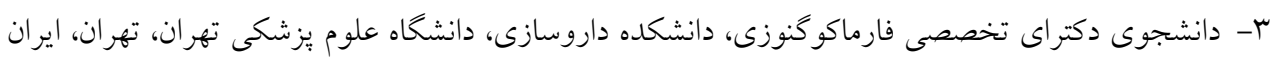

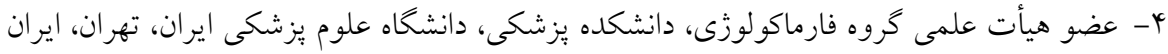

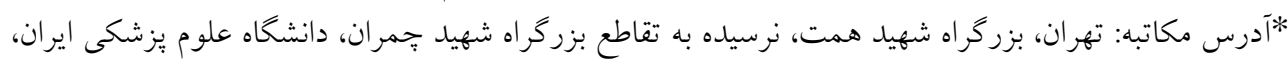

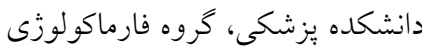

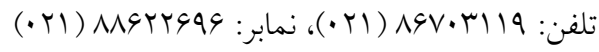 \\ بـت الكترونيك: hoormand.m@iums.ac.ir
}

تاريخ تصويب: تاريخ دريافت:

جكيده

استفاده از گياهان دارويى قدمتى به درازاى تاريخ بشرى دارد. با توجه به اين بيشينه كهن، كاربرد گياهان در بيشگيرى و درمان

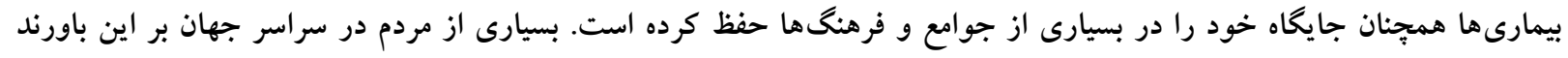

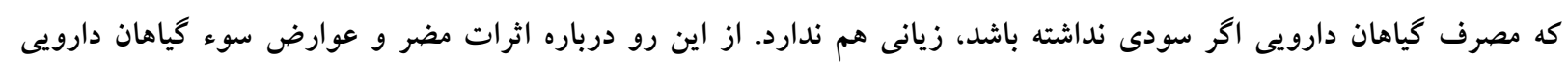

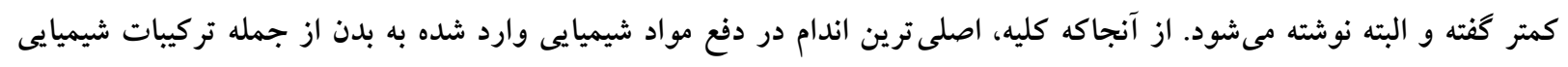

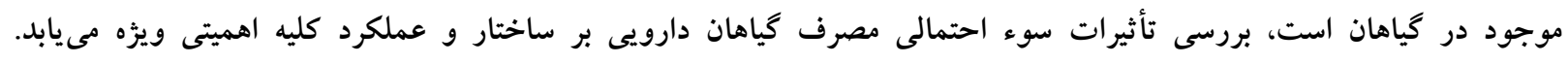

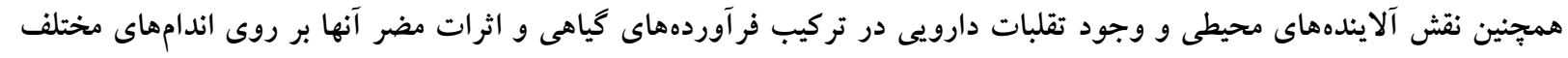

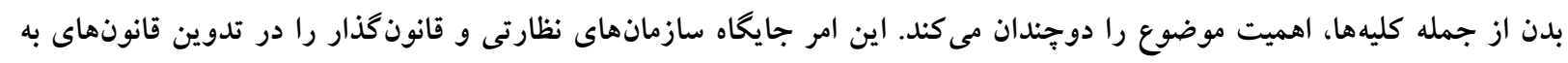

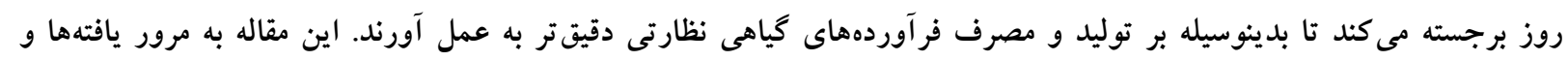

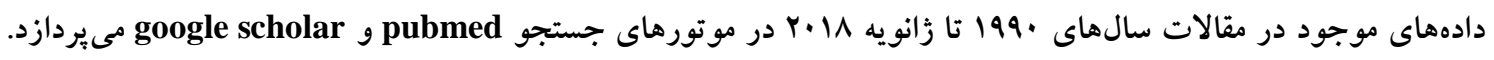
گل وازگًان: آلايندهاى محيطى، تقلبات دارويى، عوارض سوء دارويى، كليه، گياهان دارويى 
درصد افراد در آمريكا فرآوردههاى گياهى را كاملاً سالم، بدون هيج عارضه جانبى و فاقد تداخل با داروهاى ديكر تلقى مى كنند

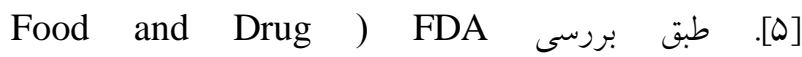
Administration كياهان دارويى توسط بيماران گزارش مىشود [9]. اين مسئله

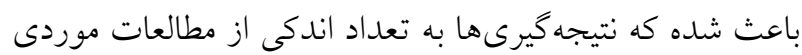

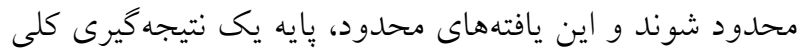

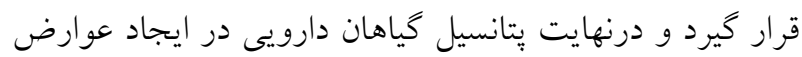

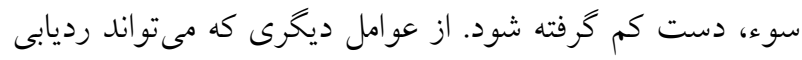

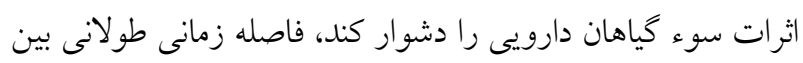
مصرف كياه و بروز اثرات مخرب آن مىباشد. مثال بارز اين مورد

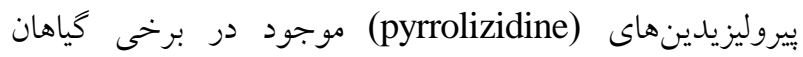

هستند كه مى توانند باعث ايجاد سيروز و سرطان شوند []. عوارض سوء ناشى از مصرف كياهان دارويى بسيارى از

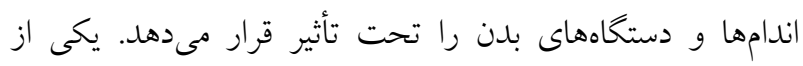

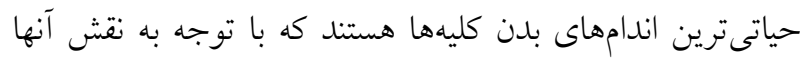

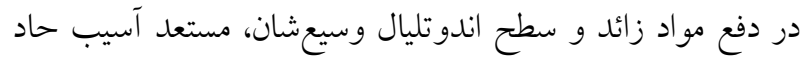
يا مزمن ناشى از مواجهه با تركيبات مختلف شيميايى هستند.

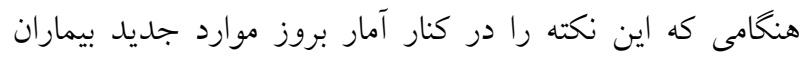

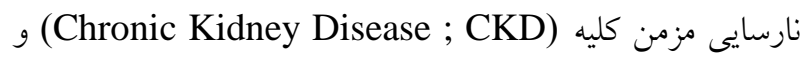

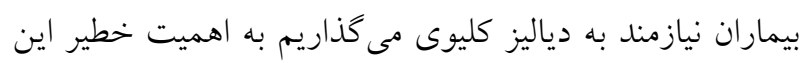

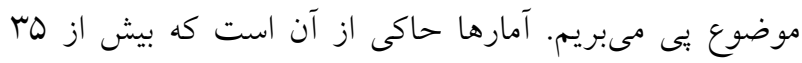

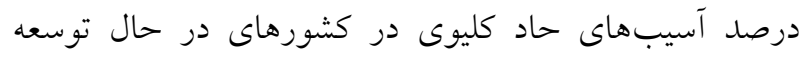

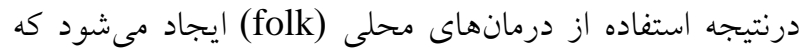

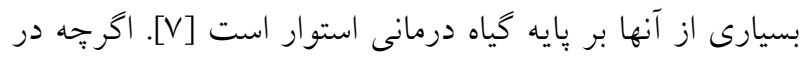

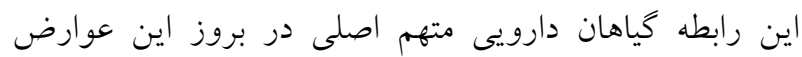

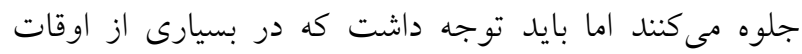

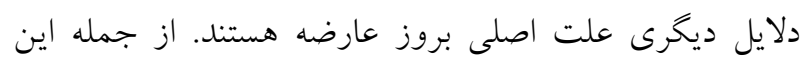

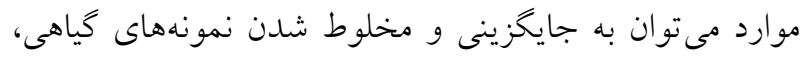

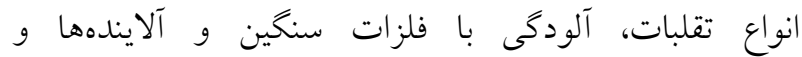

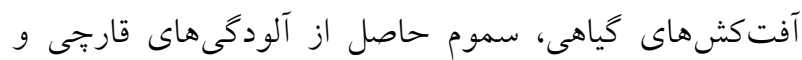

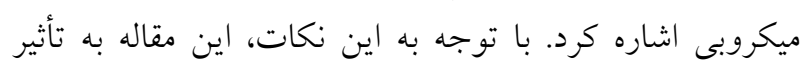

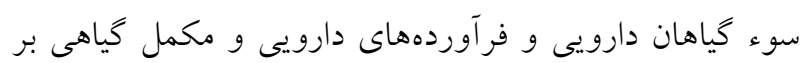

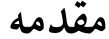

استفاده از گياهان براى درمان بيمارىها قدمتى ديرينه دارد.

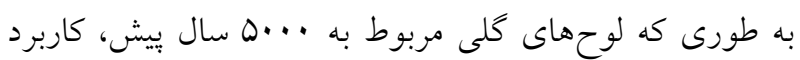

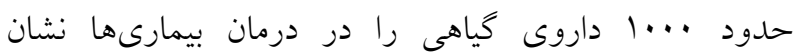

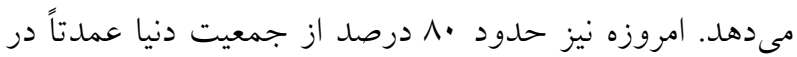
كشورهاى در حال توسعه از فرآوردههاى خياهى استفاده

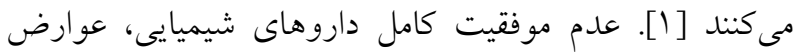

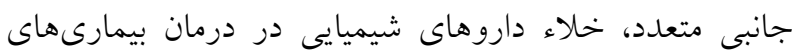

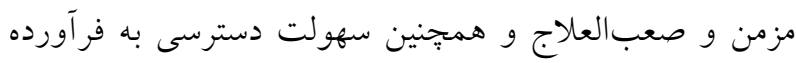

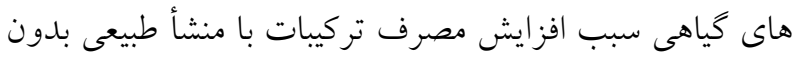

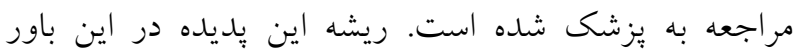

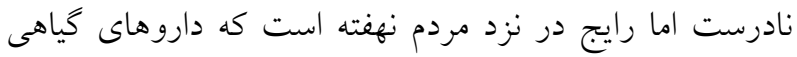
جون كه طبيعىاند حتى اگر فايدهاى نداشته باشند، ضررى نيز

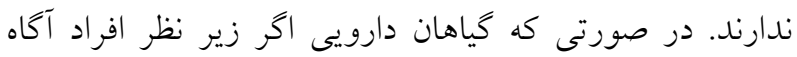
مصرف نشوند جه بسا مىتوانند حال بيمار را بدتر كنند. از از

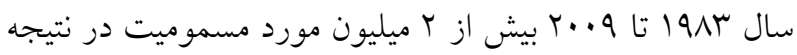

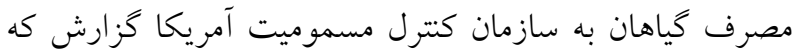

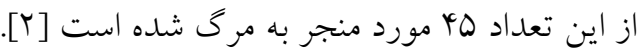

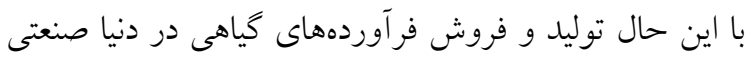

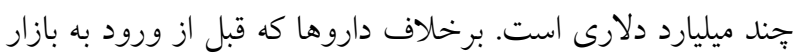
آزمايشهاى متعددى براى تعيين اثربخشى و بـى خطرى آنها انجام

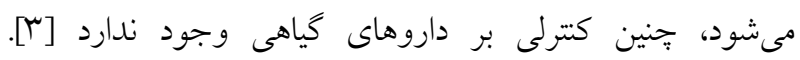

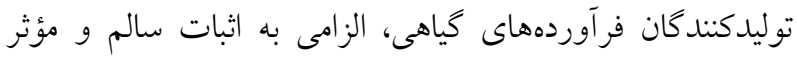

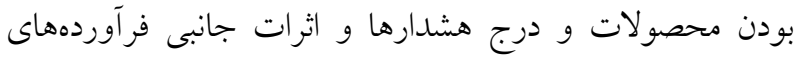

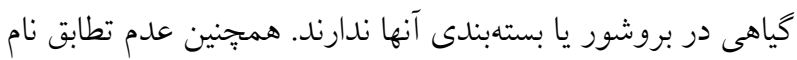

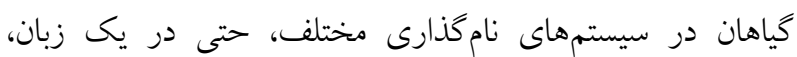

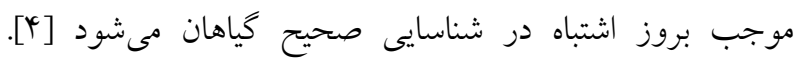
كزارشهاى متعددى مبنى بر ناخالصى يك محصول كياهى و و

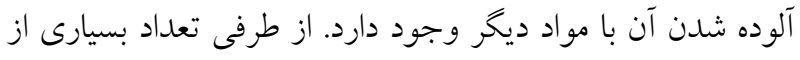
محصولات فاقد تركيباتى بودند كه بر بستهبندى آنها ذكر شده بوده.

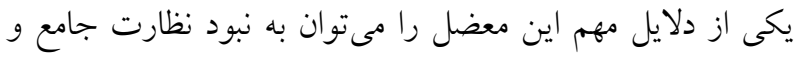
دقيق بر روند توليد صحيح و مناسب ( اين فرآوردهها دانست. بيش از ونه (Manufacturing Practice 
يا در طولانىمدت مصرف شود، ممكن است به دليل اثرات شبه

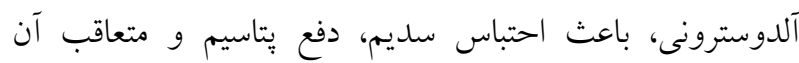

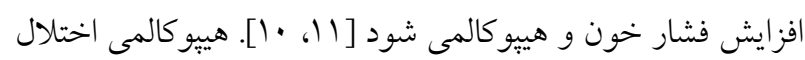

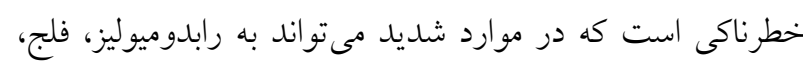

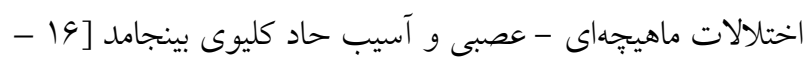

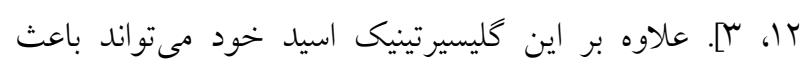

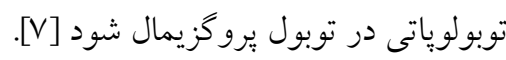

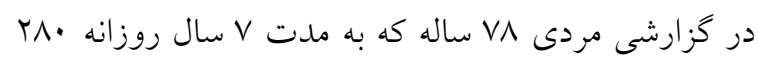

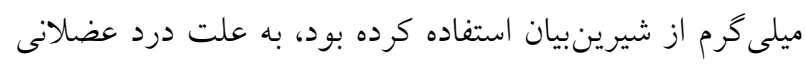

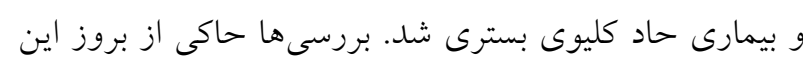

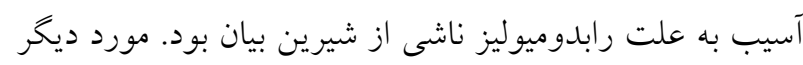

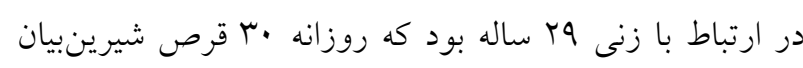

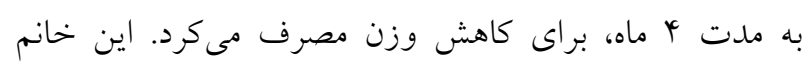
دجار ضعف عضلانى، هيبو كالمى و افزايش كراتين فسفوكيناز (CPK; Creatine Phosphokinase) نشانكر آسيب شديد سلولهاى توبولى و ايجاد تشكيلات

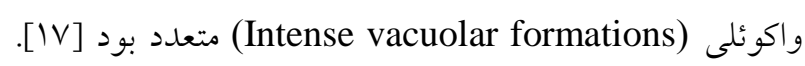

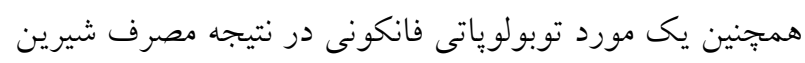
بيان گزارش شده است. كفته مىشود كه مكانيسم ايجاد

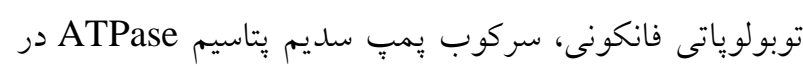

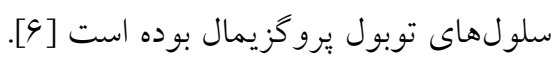

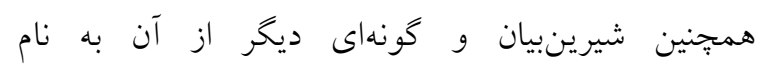
Glycyrrhiza radix

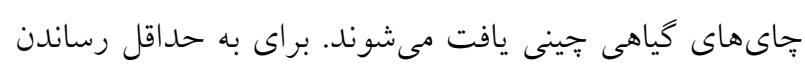

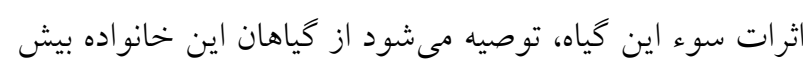

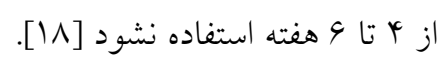

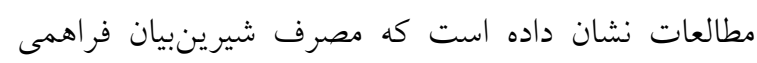

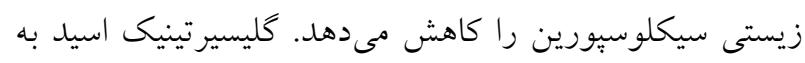

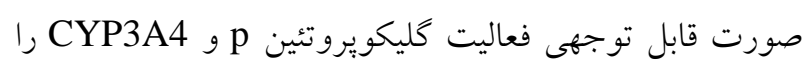

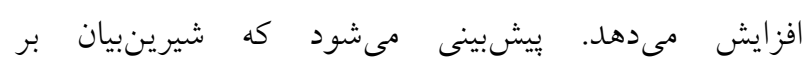

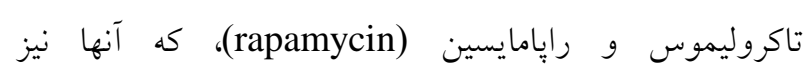

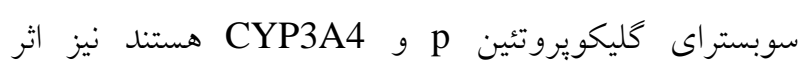

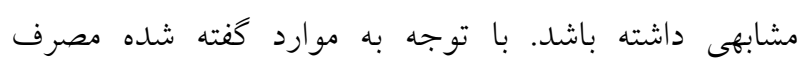

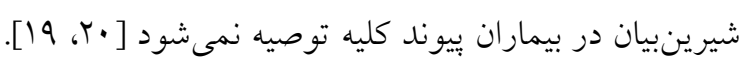

كليهها مى يردازد. بدينمنظور در موتورهاى جستجو pubmed

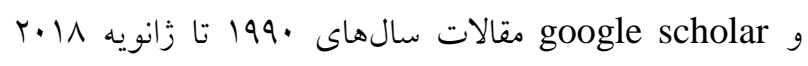
بررسى شد. به طور كلى عوارض كليوى ناشى از كَاهان دارويى را

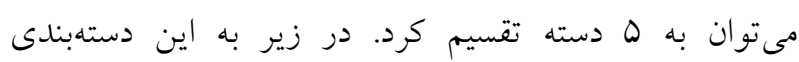
يرداخته مىشود:

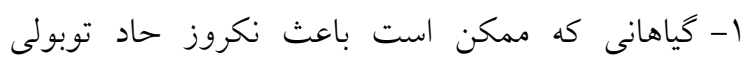
شوند. ((ATN; Acute Tubular Necrosis) r- كياهانى كه ممكن است باعث نكروز حاد بافت بينابينى (AIN; Acute Intis)

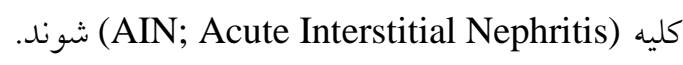
r- خياهانى كه امكان ابتلا به سنغ كليه را افزايش مىدهند. با باهانى كه ممكن است رابدوميوليز (Rhabdomyolysis) ايجاد كنند. (COX; ه- كياهانى كه با مهار آنزيم سيكلواكسيزناز ممكن است به كليه آسيب برسانند. Cyclooxygenase) - كياهانى كه مى تواند عوارض كه مليوى ايجاد كنند شيرين (Glycyrrhiza glabra)

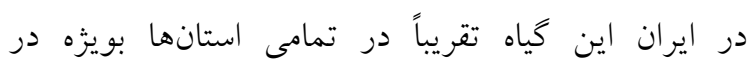
كردستان، آذربايجان غربى، كرمانشاه، فارس، كُلستان، سيستان

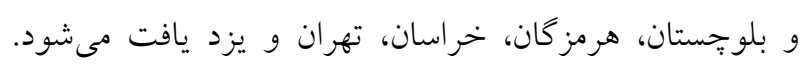

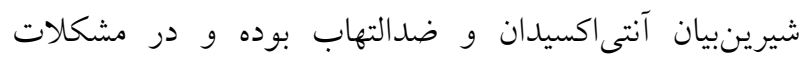

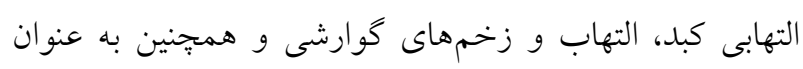
ضدلى و روشن كننده يوست كاربرد دارد [1]]. ريشه شيرين بيان حاوى كليسيريزيك اسيد ( glycyrrhizic (acid تبديل مىشود. اين ماده مىتواند (glycyrrhetenic acid)

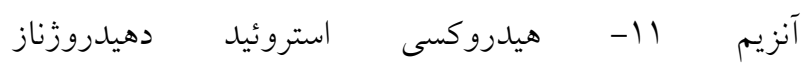
(11-hydroxysteroid dehydrogenase) درنتيجه از غيرفعال شدن كورتيزول در كليه جلوكيرى مى كند.

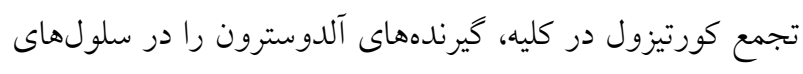

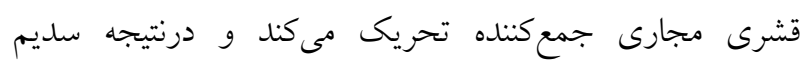

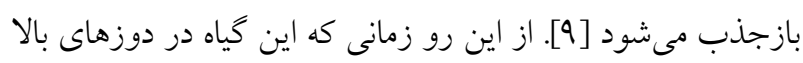




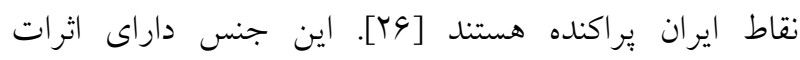

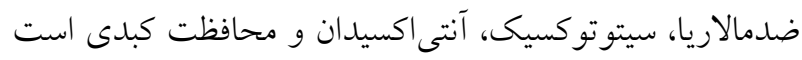
[YV] A. kermanesis و A. melanolepis كَاهان اين جنس در طب سنتى ايران جايگاه شناخته شدهاى

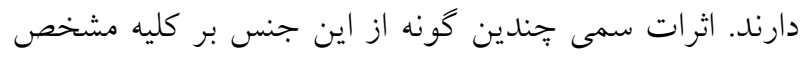
Artemisia شده است. يكى از خطرناكترين اين كياهان absinthium

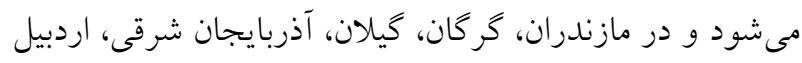

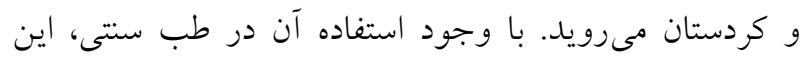

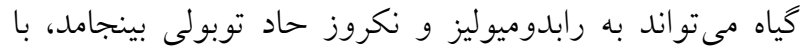

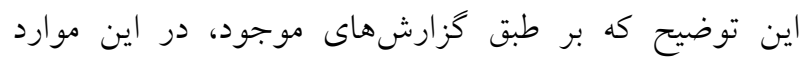

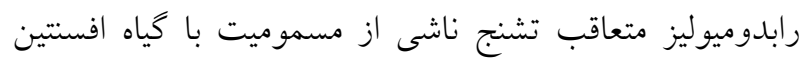

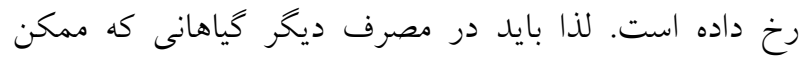

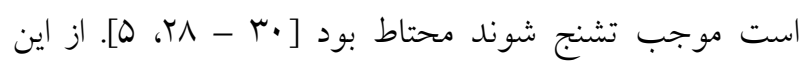

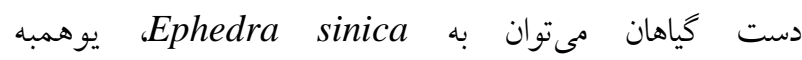
Acontum napellus كر گ شوكران آبى Cicuta virosa شاره كرد [V (Y)،

\section{جنس داتوره (Datura) (جن)}

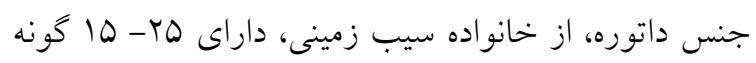

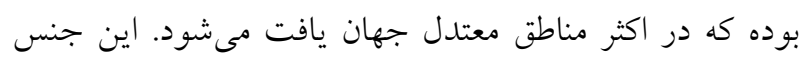

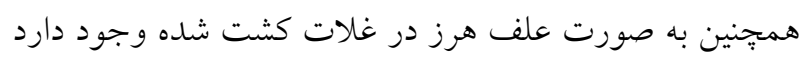

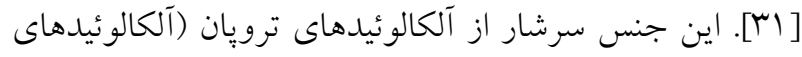

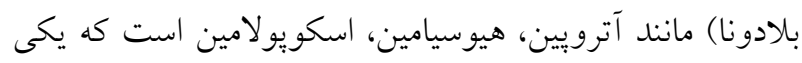

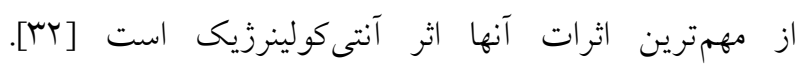

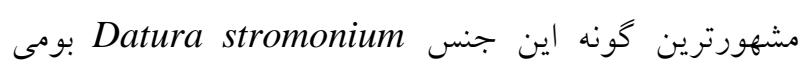

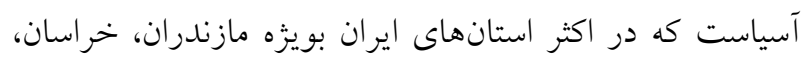

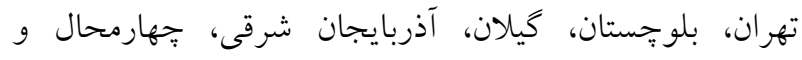

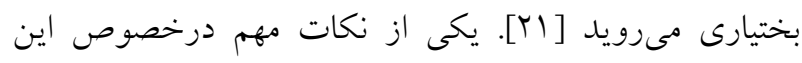

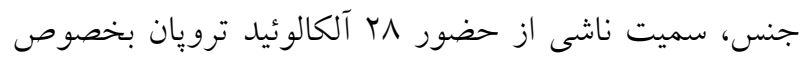

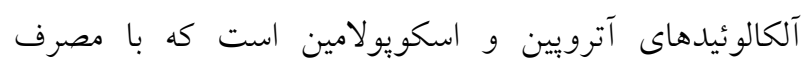

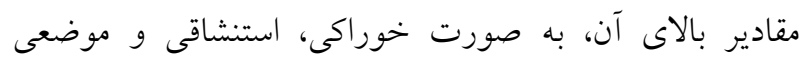

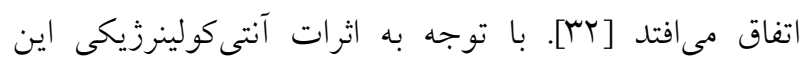

جنس افدرا (Ephedra sp)

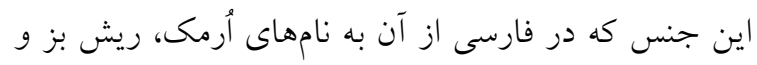

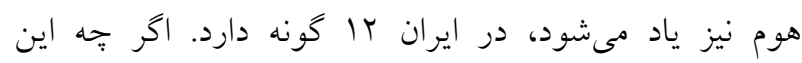

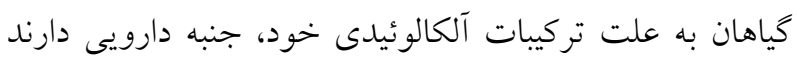
اما به علت سميت شديد جايخاهى در طب سنتى ايرانى ندارند.

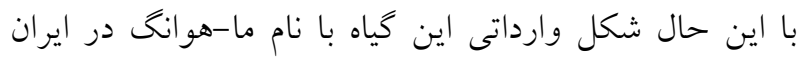

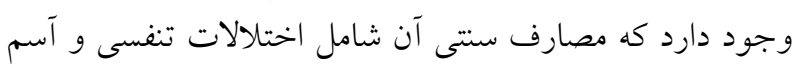

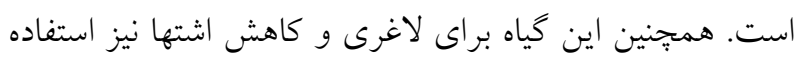

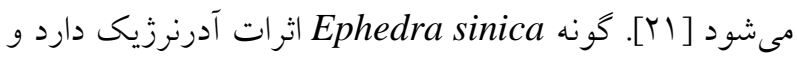

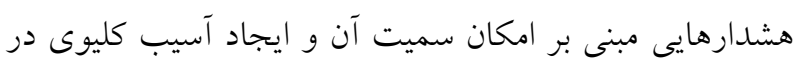

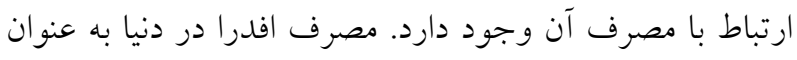

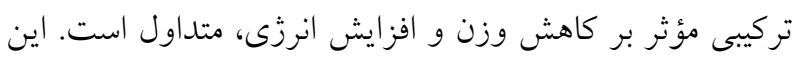

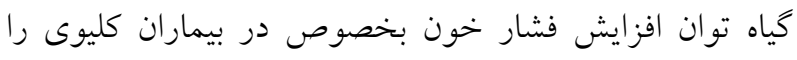

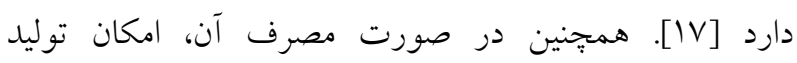

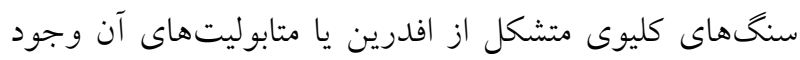

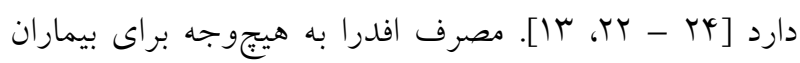

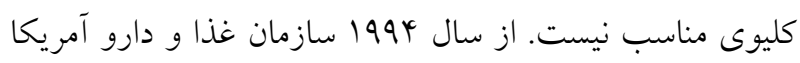

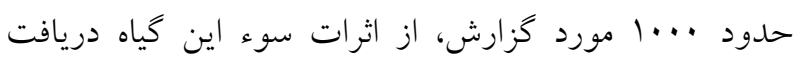

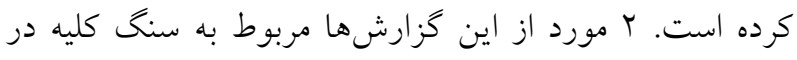

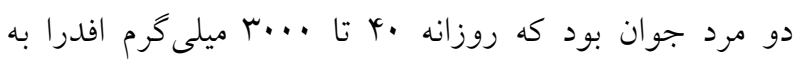

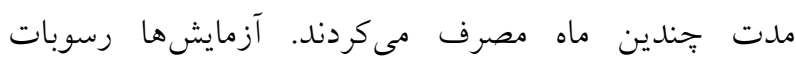

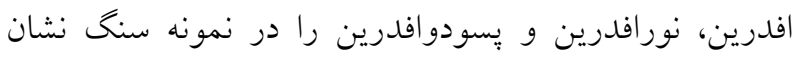

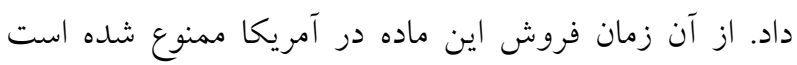

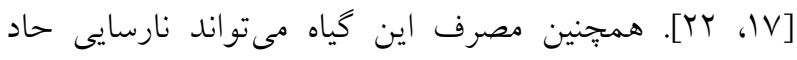

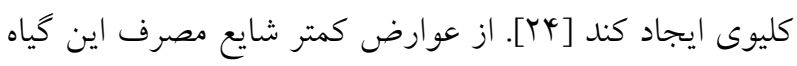

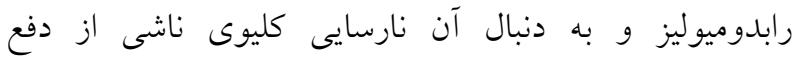

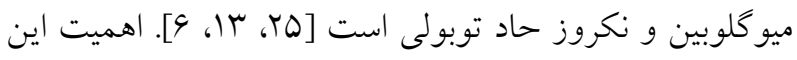

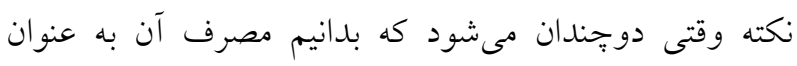

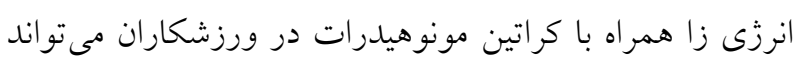

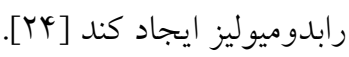

جنس درمنه (Artemisia)

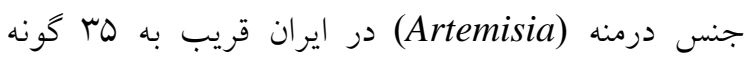

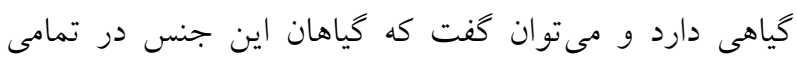


عبدالهى و همكاران

خارخاسك (Tribulus terrestris)

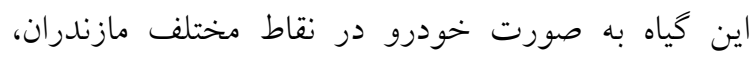
آذربايجان شرقى و غربى تا زنجان، لرستان و تهران مىروريد.

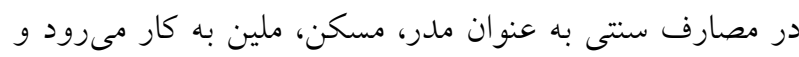

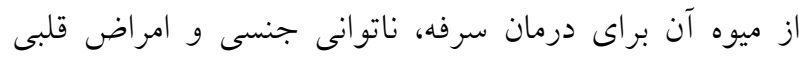

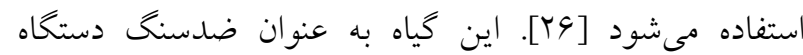

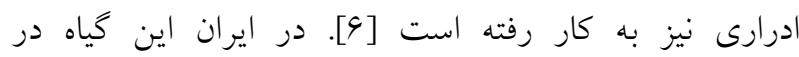

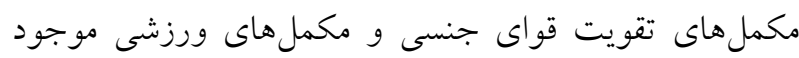

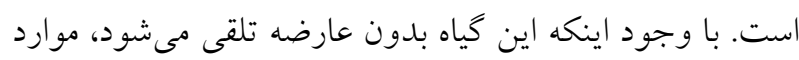

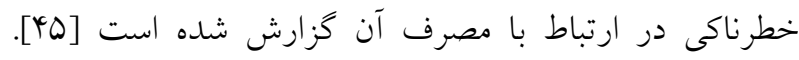

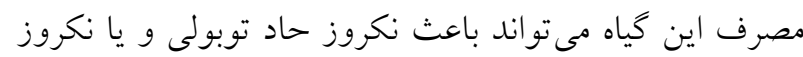

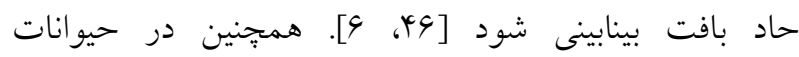

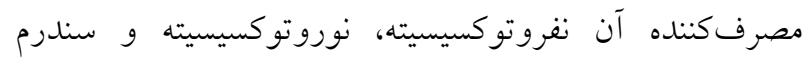

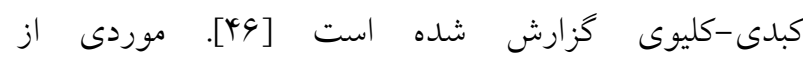

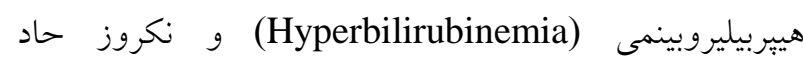

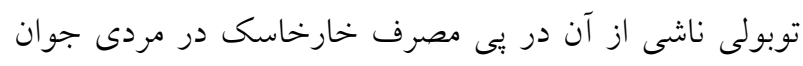

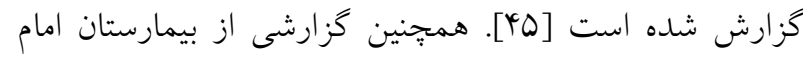

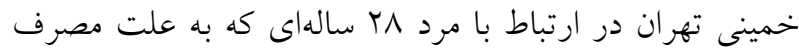

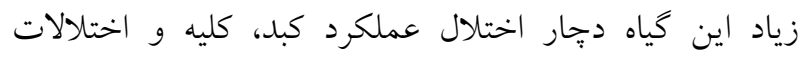

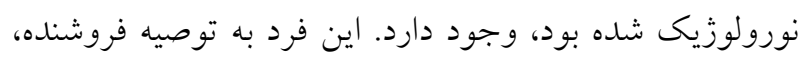

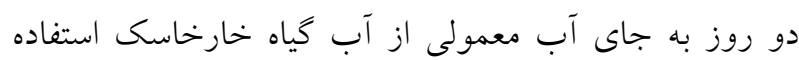

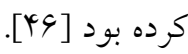

\section{Cassia obtusifolia}

جنس Cassia سرشار از تركيبات بلىفنولى و آنتراكينونهاست. به علت حضور اين تركيبات، كونههاى مختلف اين جنس به عنوان ملين و مسهل استفاده مىشوند.

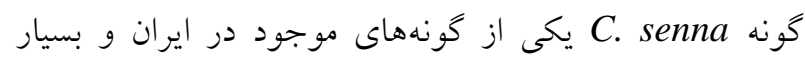

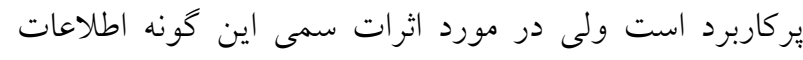

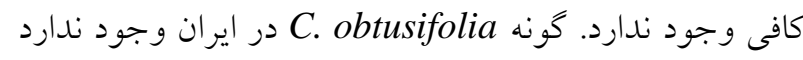
ولى در بررسى هاى انجام شده مشخص شد شد كه مى تواند منجر

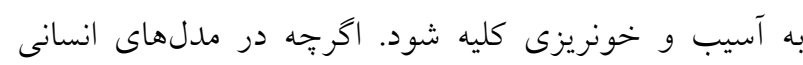

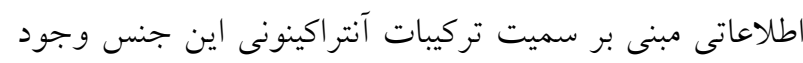

آلكالوئيدها علايم مسموميت مانند كما، تب، تاكى كاردى،

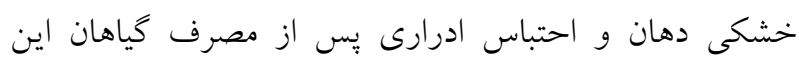

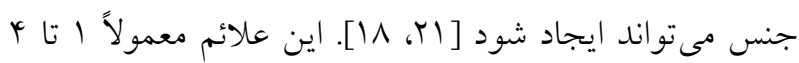

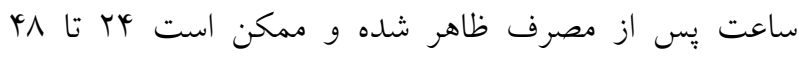

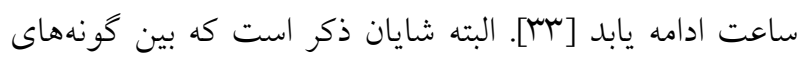

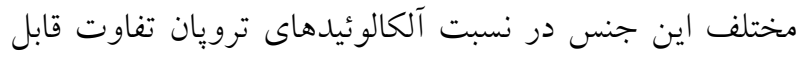

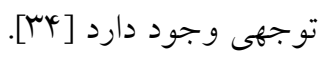

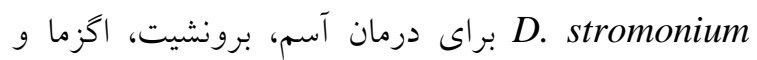

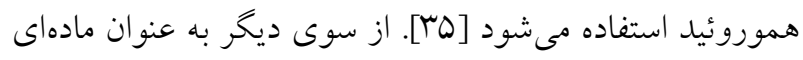

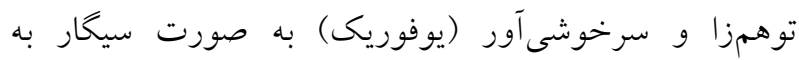

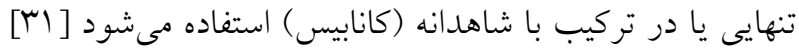

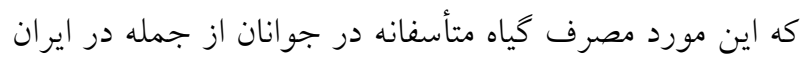

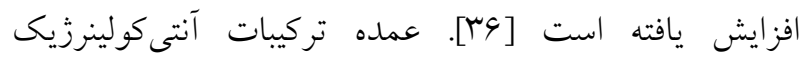

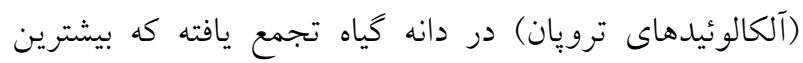

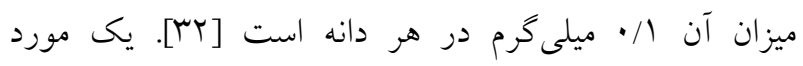
نارسايى كليه در فردى كه از ريشه داتوره براى درمان

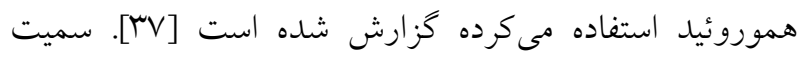

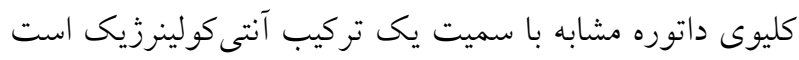

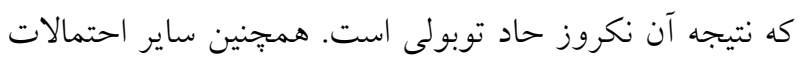

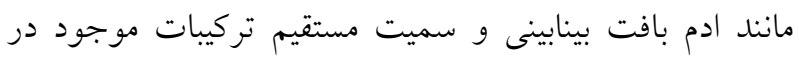

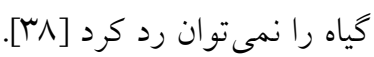

سورنجان (Colchicum autumnale)

ماده مؤثره اصلى سورنجان آلكالوئيد كولشىسين است كه

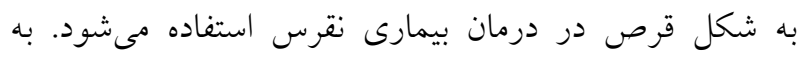
علاوه اين گياه جهت بهبود دردهاى مفصلى و سياتيك، تقويت دري

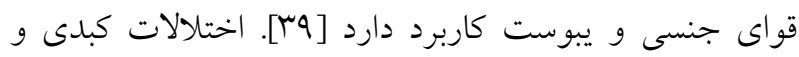

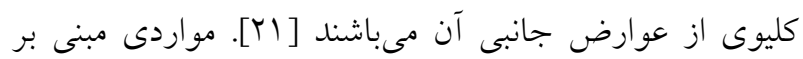

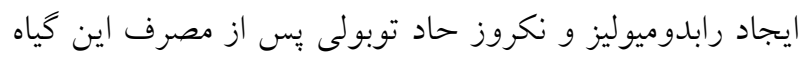

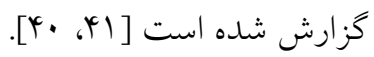

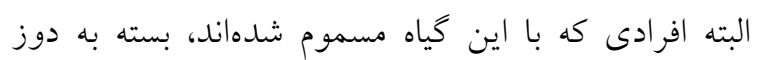

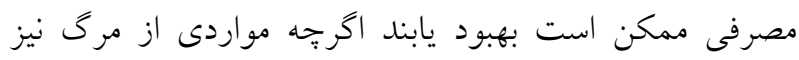

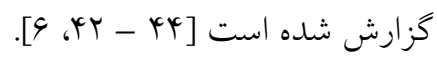


مىشود. اين گياه شامل مقادير زيادى از آريستولوشيك اسيد

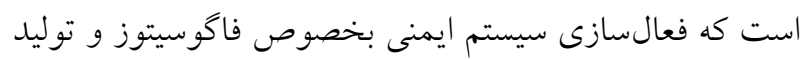

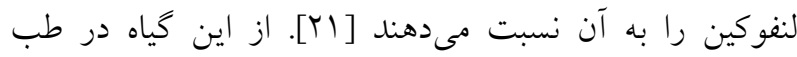
سنتى ايران براى درمان سردرد، كمردرد و اضطراب استفاده

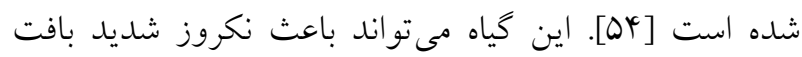

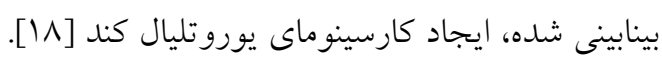

\section{ينجه گربه (Uncaria tomentosa)}

اين كياه در ايران نمىرويد اما در مكملهاى توصيه شده براى

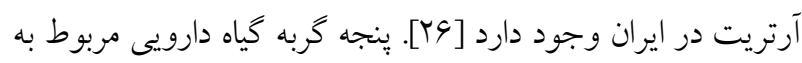

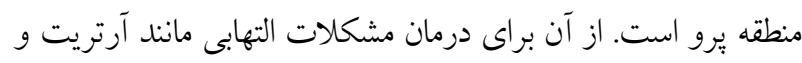

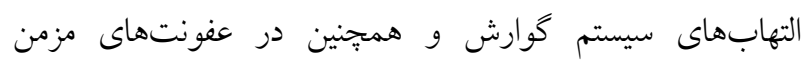

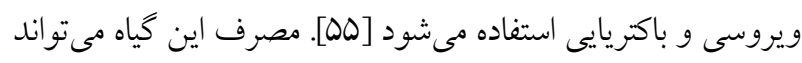

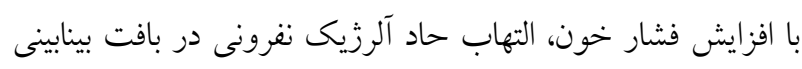
(Acute allergic interstitial nephritis)

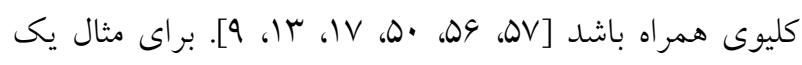

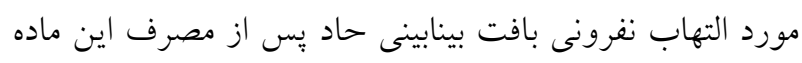

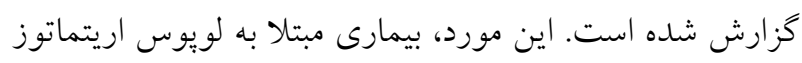

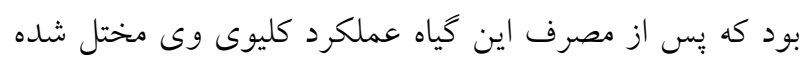

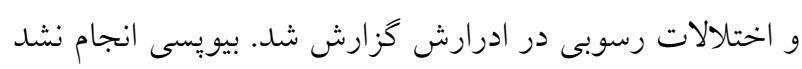

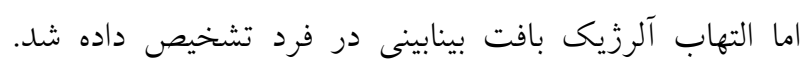

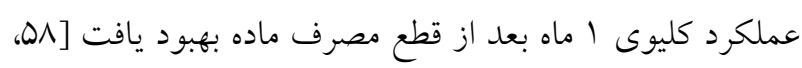

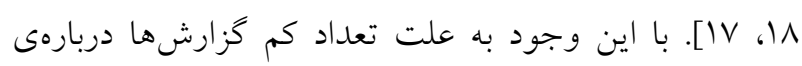

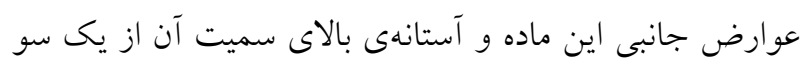

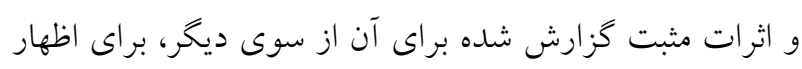
نظر به مطالعات بيشترى احتياج است. تئ.

جنس بيد (Salix)

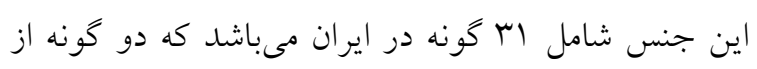

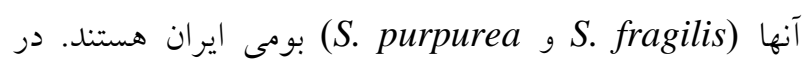

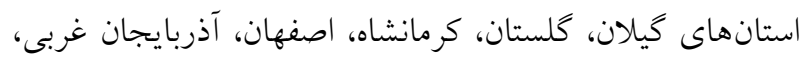

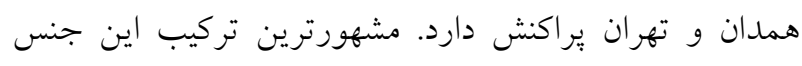

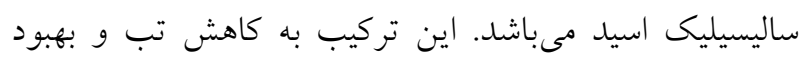

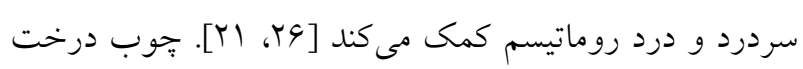

ندارد ولى بروز سميت كليوى در مدلهاى حيوانى، احتمالاً به

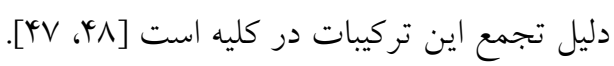

Taxus celebia

اين كياه ممكن است مستقيماً اثرات نفروتو كسيك داشته باشد و

به التهاب حاد بافت بينابينى همراه با نكروز حاد توبولى منجر شود.

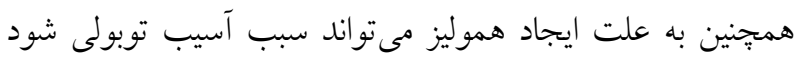

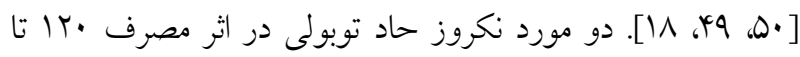

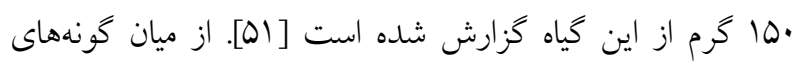

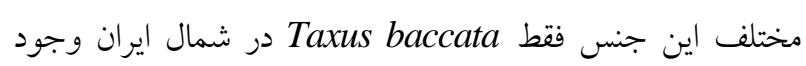

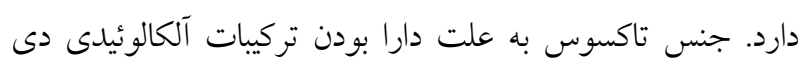
ترين بخصوص تركيب تاكسول مورد توجه بوده كه داراى اثرات

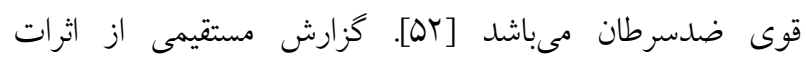
نقروتو كسيسيته اين كونه وجود ندارد.

خرزهره زرد (Thevetia peruviana)

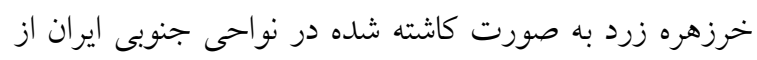

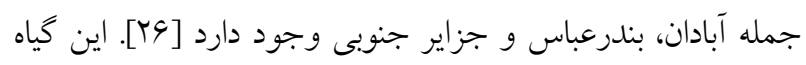

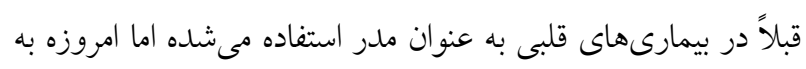
علت كليكوزيدهاى قلبى بسيار سمى موجود در آن، كمتر كاربرد

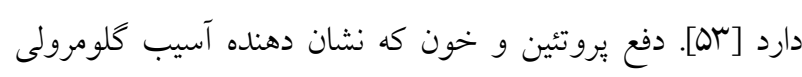

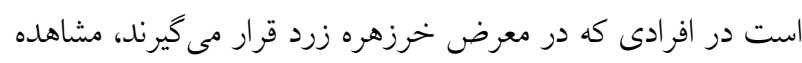

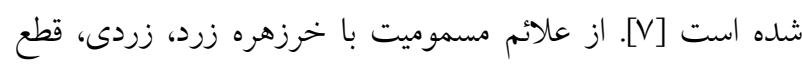

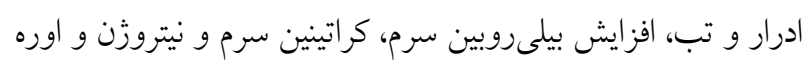
خون مىباشد. يكى از مصرفكندكان اين ماده تحت دياليز قرار

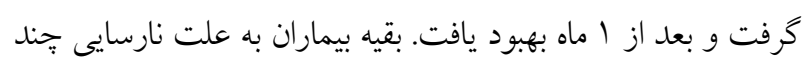

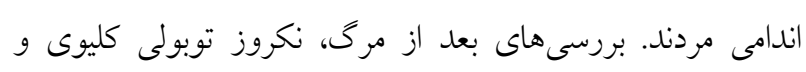

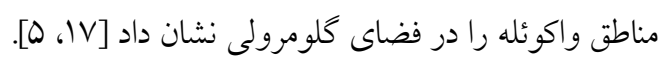

\section{-}

زراوند (Aristolochia bottae)

در ارتباط با اثرات فوق سمى اين جنس كياهى در بخش

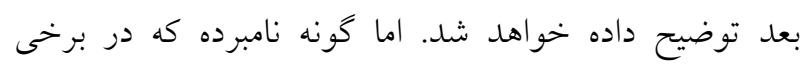
مناطق ايران يافت مىشود، براى تحريكى سيستم ايمنى استفاده 
بسيارى از مناطق كاشته مىشود. برگهاى اين گياه حاوى انواع

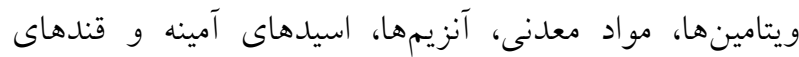

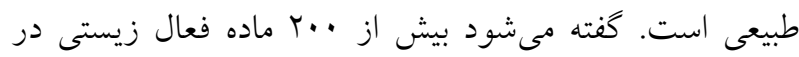

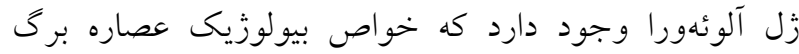

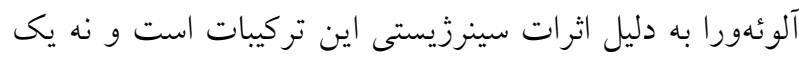

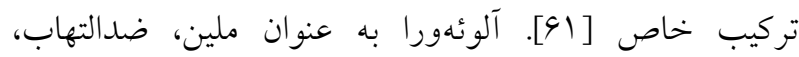

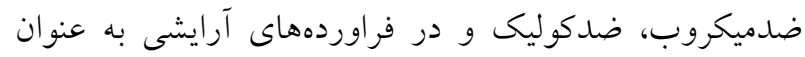

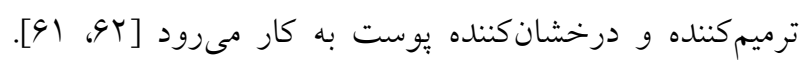

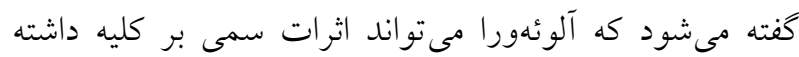

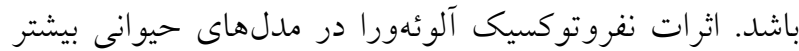
در دوزهاى بالا و زمانهاى طولانى مصرف ديده شده است.

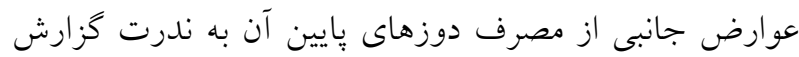

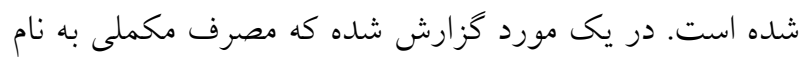
CKLS سبب نكروز بافت بينابينى شده است. احتمال مىرود آلوئمورا

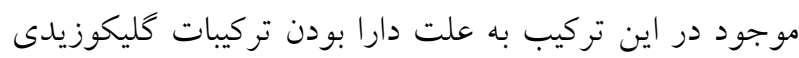

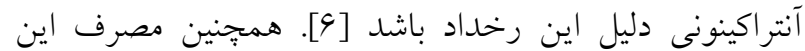

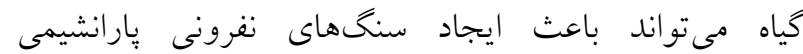
(parenchymatous nephritis)

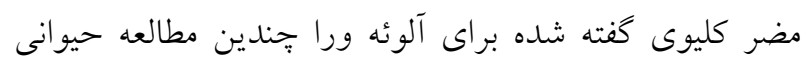

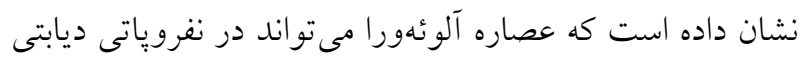

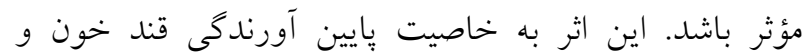

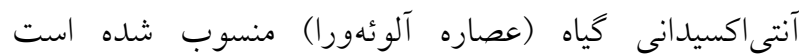

[94.90]

- كياهانى كه امكان ابتلا به سنگ كليه را افزايش مىدهند:

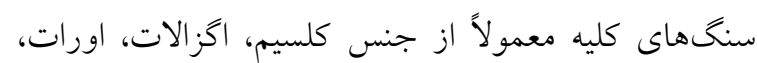

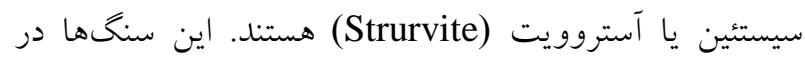

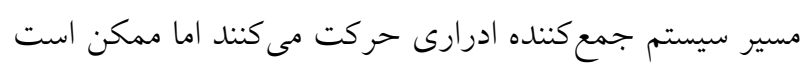

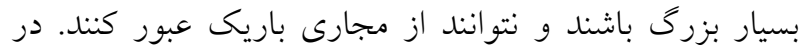

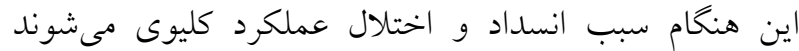

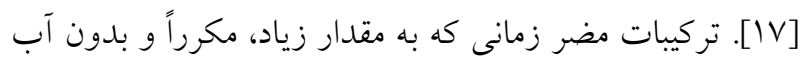
كافى مصرف شوند، ممكن است باعث ايجاد سنگ كليه و
جنس بيد، حاوى ساليسين (salicin) مىباشد كه در بدن به

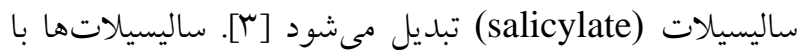
مهار بروستاكلندينها و كاهش جريان خون كليه باعث اختلال

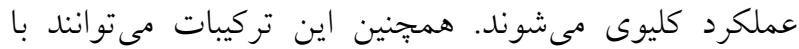
انقباض عروق باعث كاهش جريان خون كليوى و درنهايت

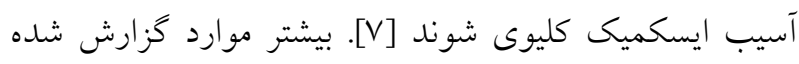

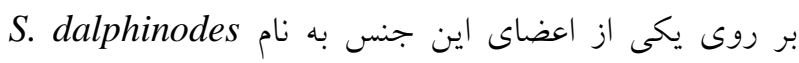

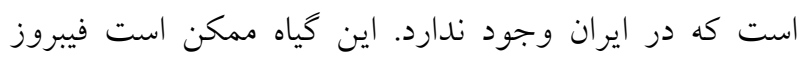

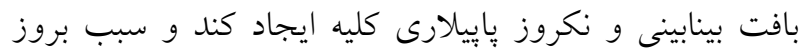

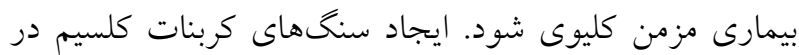

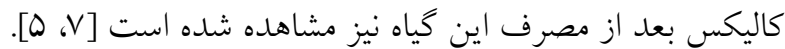

خارخاسك بخش مربوط به (اكياهانى كه ممكن است باعث ATN شوند، پاراگر اف خارخاسك (Tribulus terrestris))، را مطالعه نماييد.

\section{يوهمبه (Pausinystalia yohimbe)}

يوهمبين آلكالوئيد اصلى اين كياه است كه از يوست درخت يوهمبه به دست مى آيد [09]. خود كياه يا ماده مؤثره

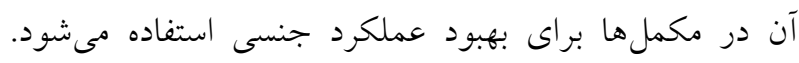

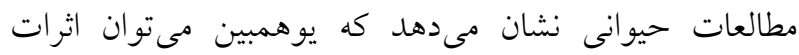

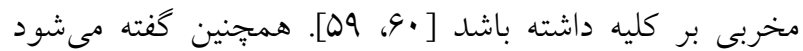
اين كياه مىتواند باعث لويوس اريتماتوز سيستميك (SLE) Systemic Lupus Erythematosus ابتلا به سندرم مشابه SLE با دفع يروتئين و نارسايى كليوى

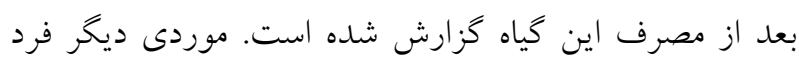

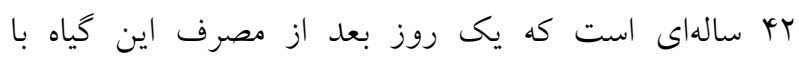

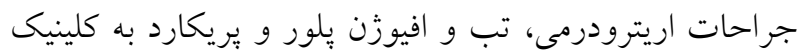

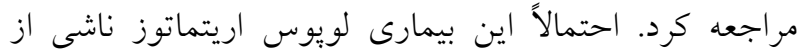
يوهمبين بوده كه به نقص كاركرد كليه انجاميده است [IV]

صبر زرد (Aloe vera) اين كياه از سالهاى دور در ايران به بهن عنوان كياه دارويى

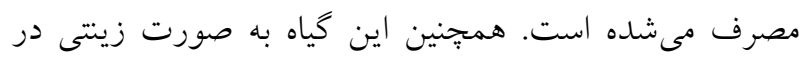


جنس ترشك (Rumex)

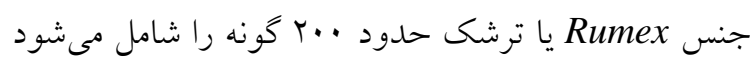

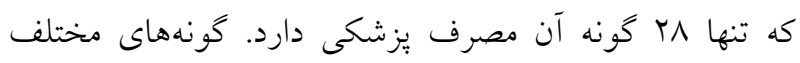

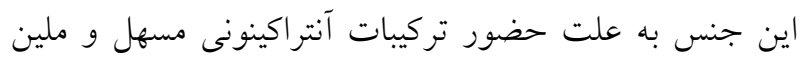
بوده و جهت درمان يبوست استفاده مىشوند. علاوه بر اين در بهبود مشكلات يوستى و التهاب نيز مؤثر هستند. برخى از كونه هاى ترشك حاوى مقادير بالايى اخزاليى اسيد مىباشند.

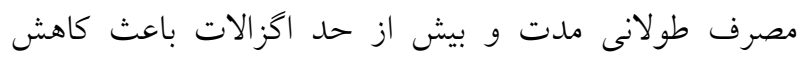

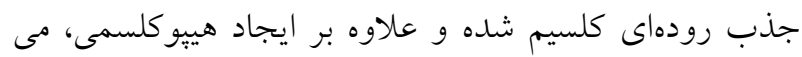

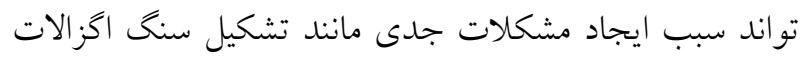

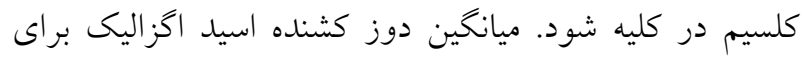

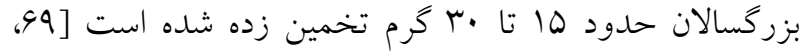

افدرا، ارمك، ريش بز، هوم (Ephedra)

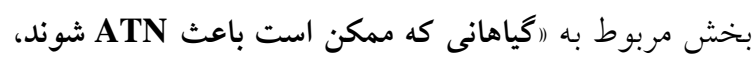
ياراخراف جنس افدرا (Ephedra sp)) را مطالعه نماييد. - كياهانى كه ممكن است رابدوميوليز ايجاد كنند:

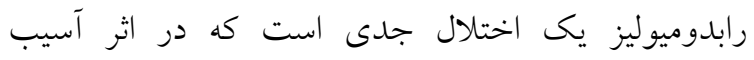
ماهيجهها و آزاد شدن محتواى آنها به جريان خون ايجاد الئاد

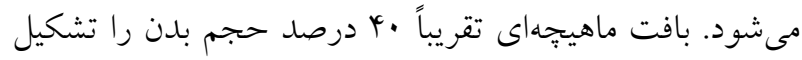
مىدهد. اين بافت ممكن است به دلايل متعددى از جمله قرار

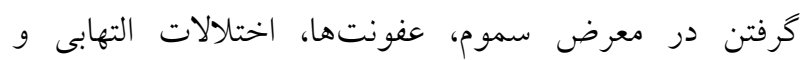

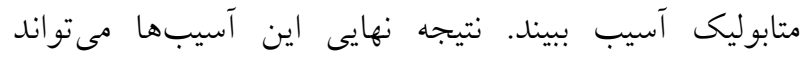

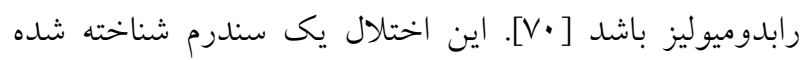

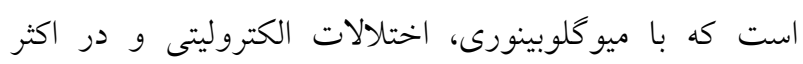

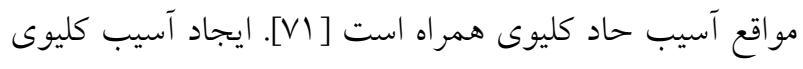
در يى رابدوميوليز مكانيسمهاى متعددى دارد. يكى از مهمترين اين مكانيسمها، تجمع ميوكلوبين در توبولهاى كليوى است.

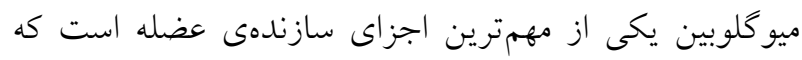

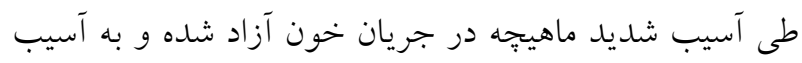

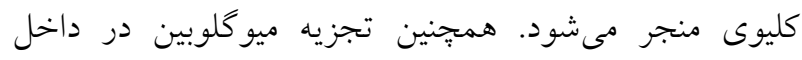

التهاب مزمن بافت بينابينى شوند [س]. در زير جنا ند نمونه از كياهان با خاصيت ايجاد سنگ نام برده شده است:

كرن برى (Vaccinium macrocarpon) اين كونه در ايران وجود ندارد اما در مكمله هاى موجود در

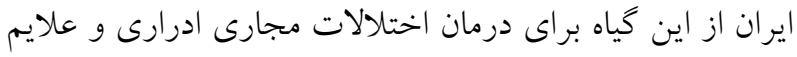

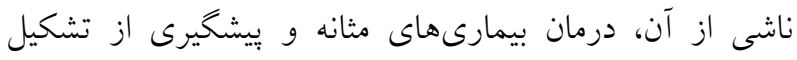

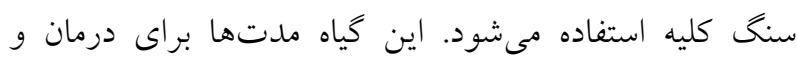

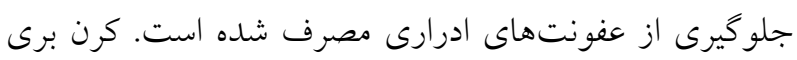

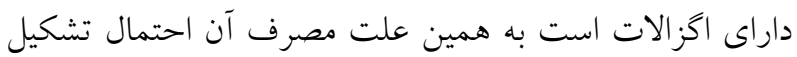
سنگ اخزالاته را در كليه بالا مىبرد [99، 9.

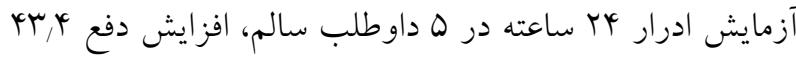
درصدى اگزالات را به دنبال مصرف كرن برى نشان داد [11].

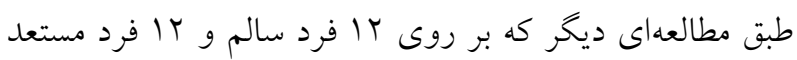

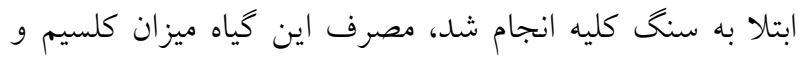

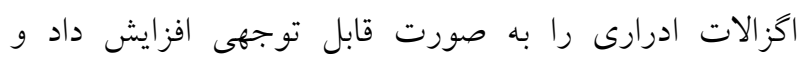

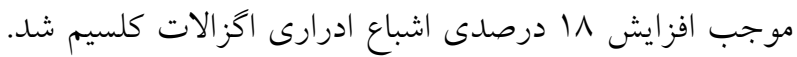
در اين مطالعه مقدار سيترات ادرارى بدون تغيير ماند و منيزيم

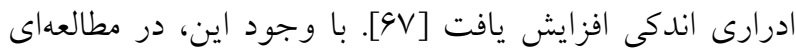

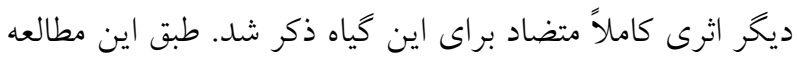

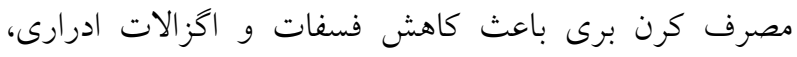

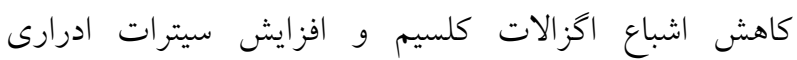

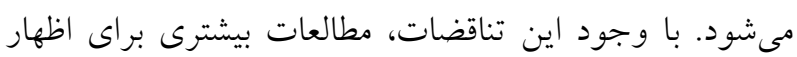
نظر قطعى لازم است. از ديخر گونههاى اين گياه در ايران Vaccinium arctostaphylos

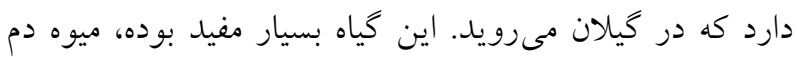

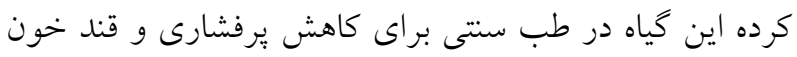

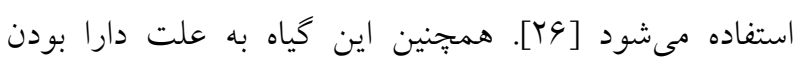

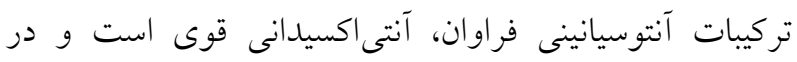

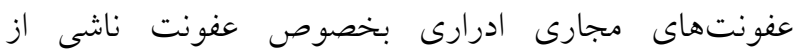
E. coli

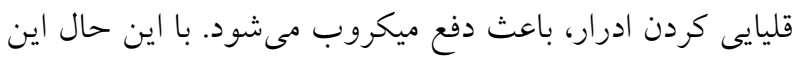

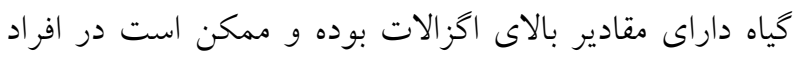
مستعد ابتلا به سنگ كليه ايجاد مشكل نمايد [ [Y]". 
سورنجان (Colchicum autumnale)

بخش مربوط به "اكياهانى كه ممكن است باعث ATN

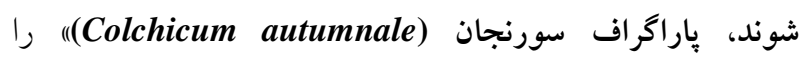

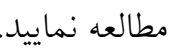

\section{Commiphora mukul} Commiphora mukul

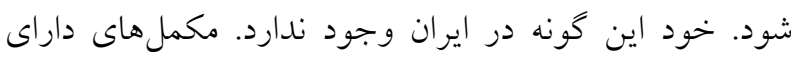
عصاره اين كياه به نام gugul وجود دارند كه براى كاهش آنش كلسترول خون و بهبود مشكلات التهابى مثل آرتريت استفاده

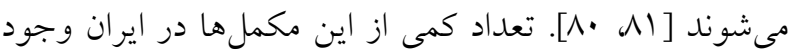

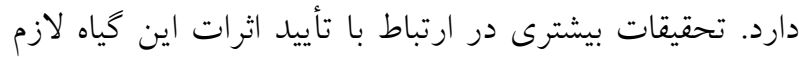

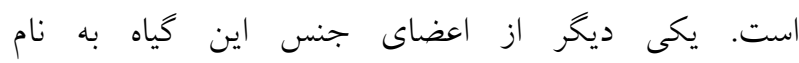
Comiphora molmol دارد و با نام مرمكى يا مير شناخته مىشود. اين كونه اثر ائران

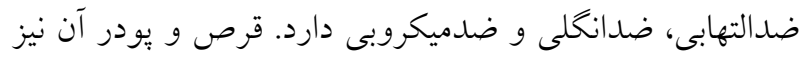

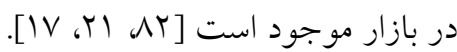

- كياهانى كه با مهار آنزيم COX مىتواند به كليه آسيب

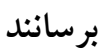

آنزيم سيكلواكسيزناز حداقل دو ايزوفرم دارد: COX1, باندم

COX2

COX1 عمدتاً در سلولهاى غير التهابى بيان مىشود، حال آنكه

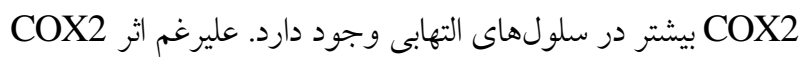

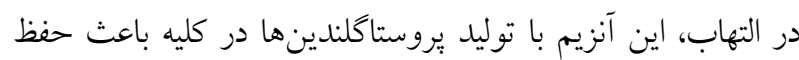

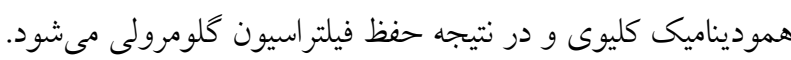

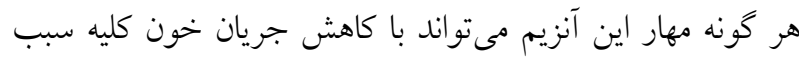

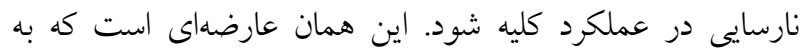
NSAIDs; ) نفروياتى ناشى از داروهاى ضدالتهاب غيراستروئيدى Nonsteroidal Anti-Inflammatory Drugs) بنابراين هر تركيبى كه بر فعاليت آنزيم COX اثر مهارى داشته

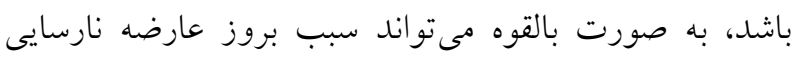

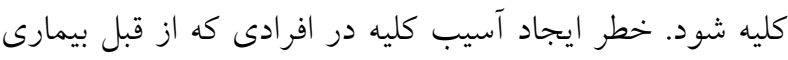

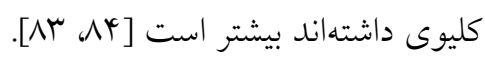

توبولها باعث رها شدن آهن آزاد مىشود. اين فرايند با توليد

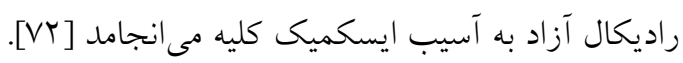

شيرينبيان (Glycyrrhiza glabra) بخش مربوط به (اگياهانى كه ممكن است باعث ATN شوند، (پاراكراف شيرين بيان (Glycyrrhiza glabra))، را مطالعه نماييد.

ماريجوانا، شاهدانه، حشيش (Cannabis sativa)

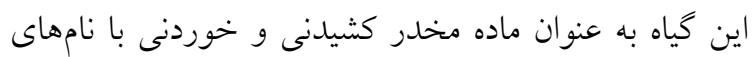

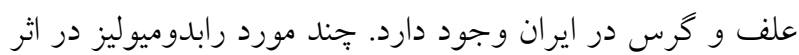
تزريق داخل وريدى عصاره گياه ماريجوانا كزارش شده است

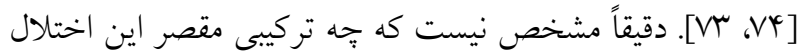

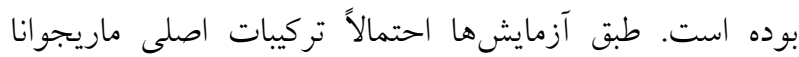

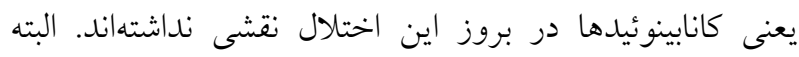

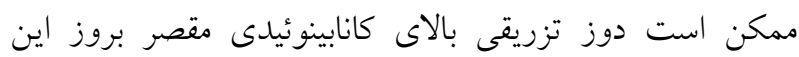

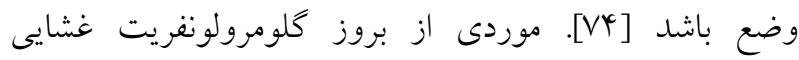
كزارش شده كه در (membranous glomerulonephritis) آن فرد مبتلا به مدت طولانى از دوز بالاى ماريجوانا استفاده

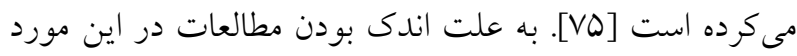

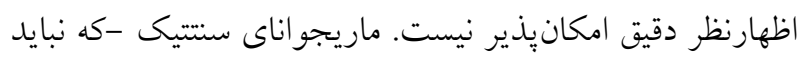

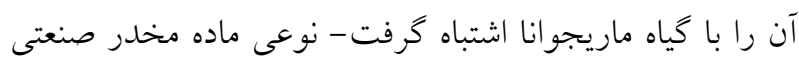
است كه با اتصال به كيرندهاى كانابينوئيدى اثراتى مشابه

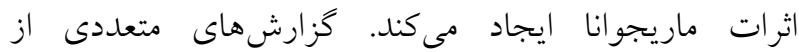

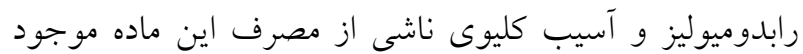

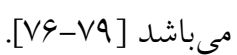

افدرا، ارمك، ريش بز، هوم (Ephedra)

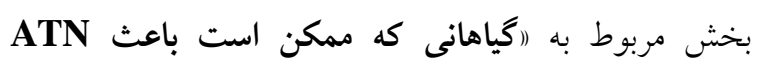
شوند، بِاراكراف جنس افدرا (Ephedra sp)) را مطالعه نماييد.

\section{افسنتين (Artemisia absinthium)}

بخش مربوط به (اگياهانى كه ممكن است باعث ATN شوند، ياراگر اف جنس درمنه (Artemisia))، را مطالعه نماييد. 
شاه بلوط هندى (Aesculus hippocastanum)

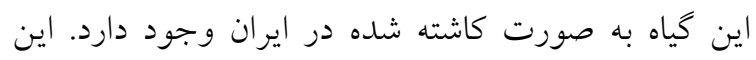

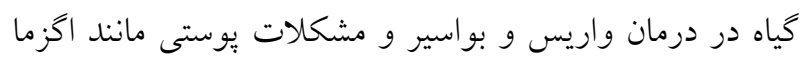

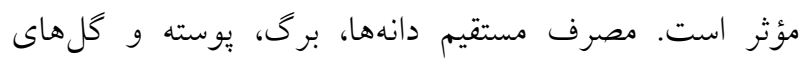
نارس و خام شاه بلوط هندى ممكن است باعث مرى شود

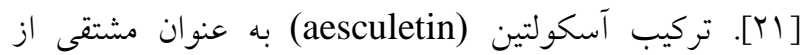

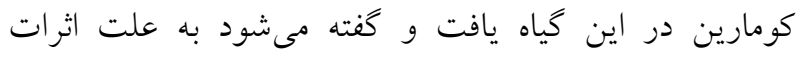
ضدانعقادى خود مىتواند باعث خونريزى شود. در موردى ائى

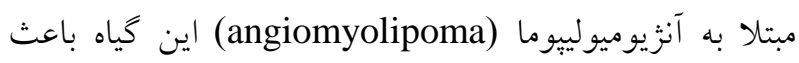

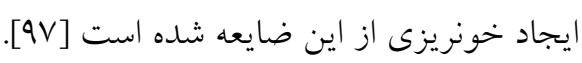

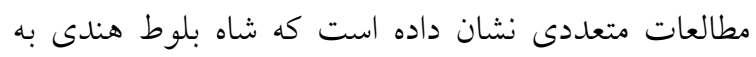

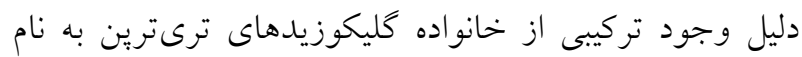

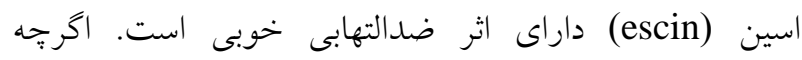
دربارهى مكانيسم اثر ضدالتهابى اسين توافق نظر وجود ندائ ندارد.

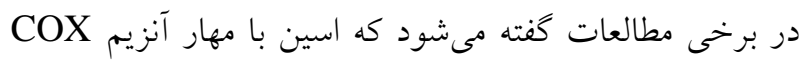

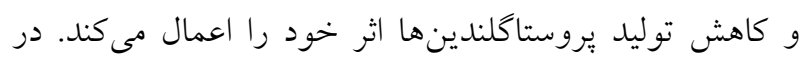

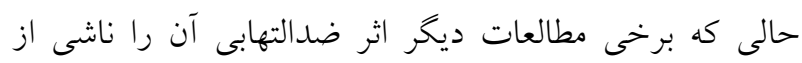
فعالسازى كيرنده گلوكوكورتيكوئيدى و مهار فاكتور رونويسى دانى Nuclear Factor Kappa-light-chain-) NF-kB مى (enhancer of activated B cells اين كونه نتيجه كيرى كرد كه از آنجا كه فعال شدن كيرندان

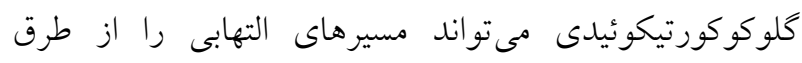

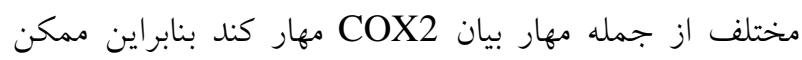

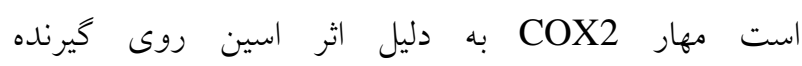

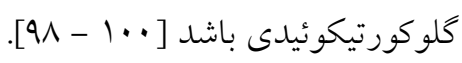

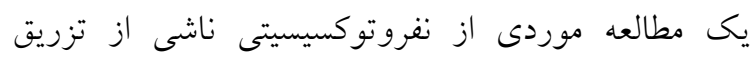

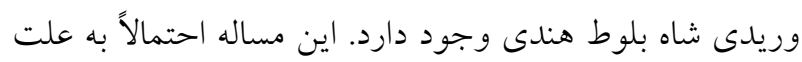

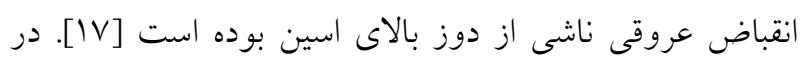

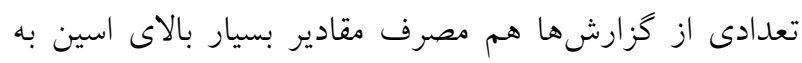
صورت خوراكى به نارسايى حاد كليوى منجر شده است. البته

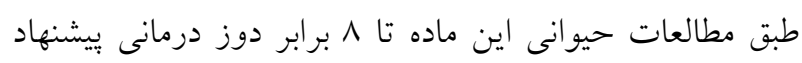

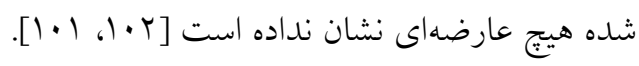

$$
\text { در زير به جند گَياه دارويى اشاره شده است: }
$$

Filipendula ulmaria عروس جمنزار ارويايى

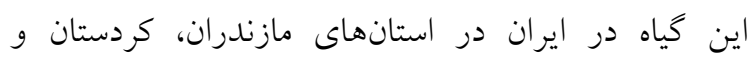

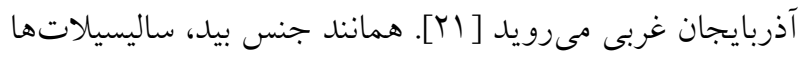

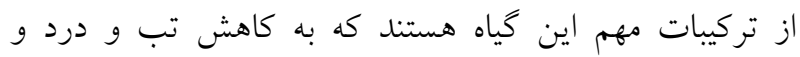

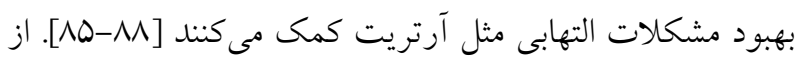
تركيبات ديخر اين كياه مىتوان به فلاونوييدها و تاننها اشتهاره

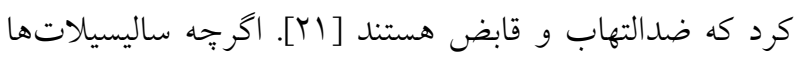

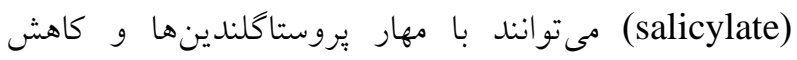
جريان خون كليه باعث اختلال عملكرد كليوى شوند [V]، اما

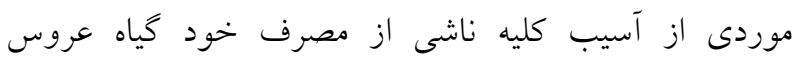

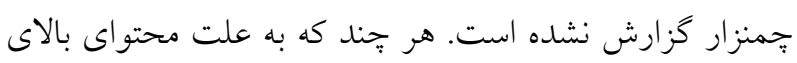
ساليسيلات آن بايد محتاط بود.

\section{زنجبيل (Zingiber officinale)}

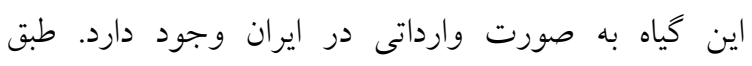

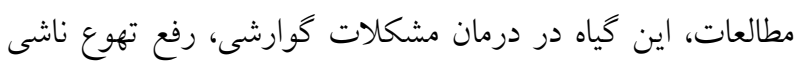

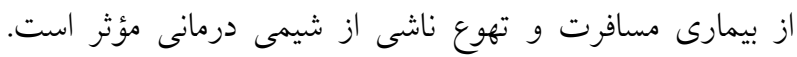

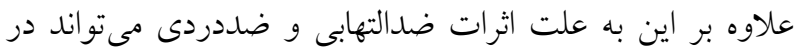

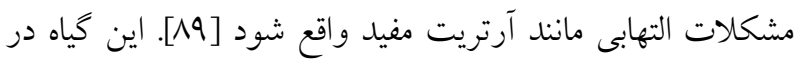

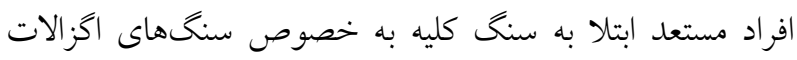

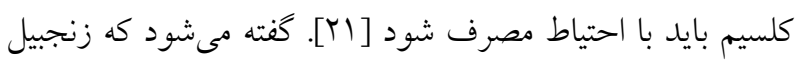

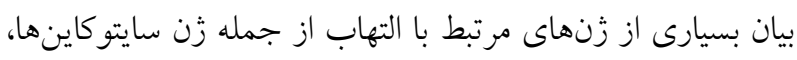

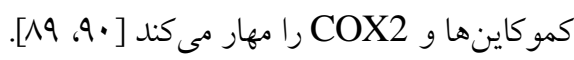

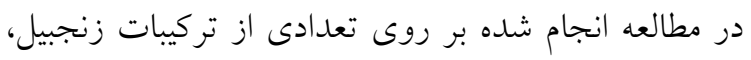

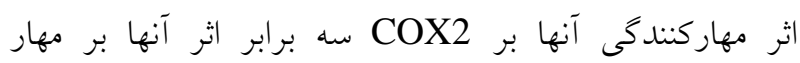

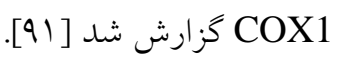
همانطور كه كفته شد مهاركنندهاى COX2

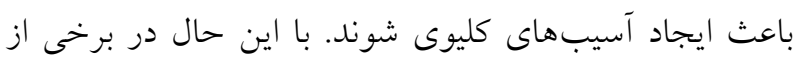

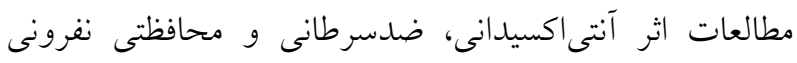

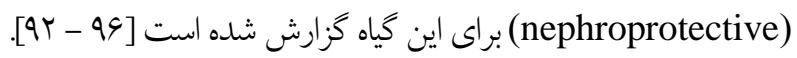


مىشود [111]. همجينين طبق مطالعات، كندر توليد NF-kB را

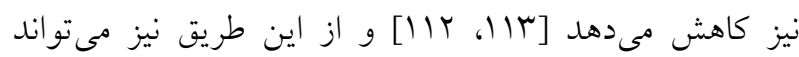

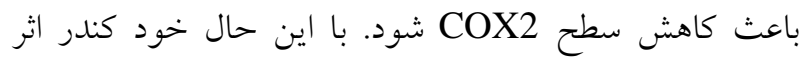

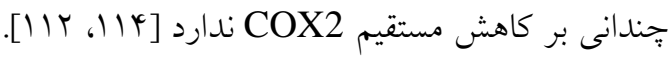

جاى سبز (Camellia sinensis) جاى بيشتر در استان كيلان و مازندران كاشته مىشود.

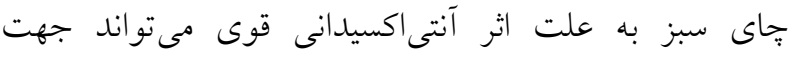

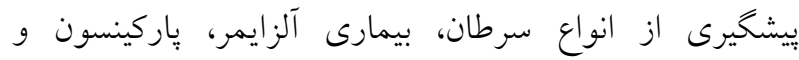

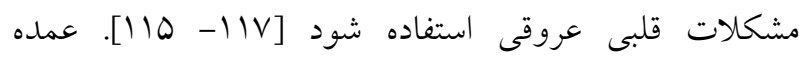

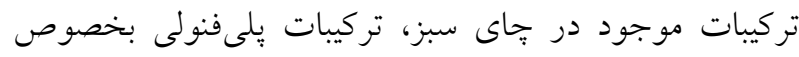

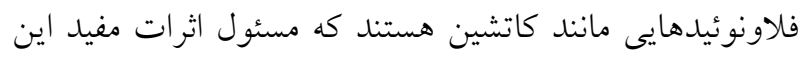

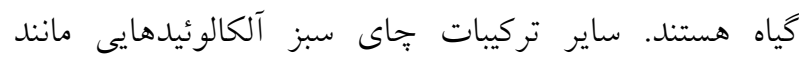

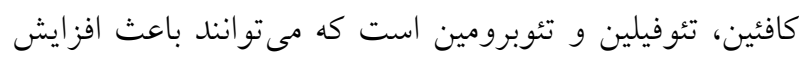
فشار خون و اثرات ديورتيك شوند. البته ذكر اين نكته اهميت

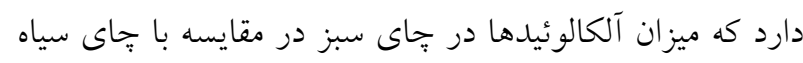
بسيار كمتر و ميزان تركيبات يلى فنولى آن بيشتر است. بنابراين

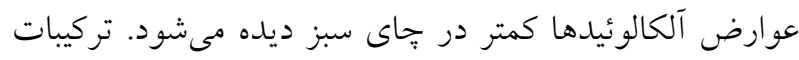

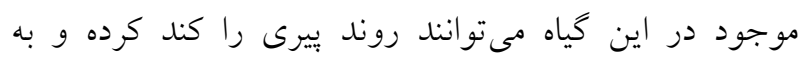

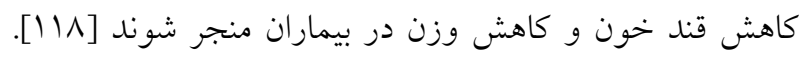
يكى از مواد مؤثر اين كياه Epigallocatechin ) EGCG (Gallate

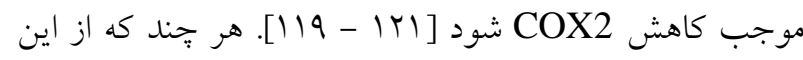

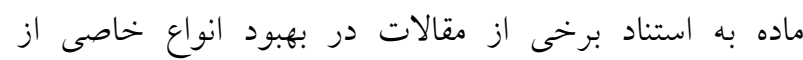

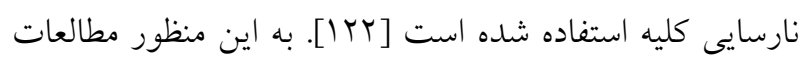

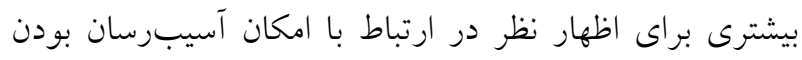

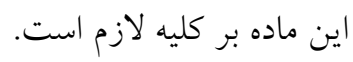

\section{بيد Salix}

بخش مربوط به ا(گياهانى كه ممكن است باعث AIN كليه شوند، باراگر اف جنس بيد (Salix))، را مطالعه نماييد.

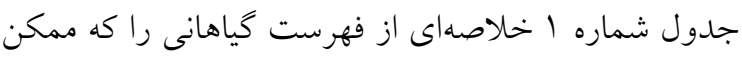

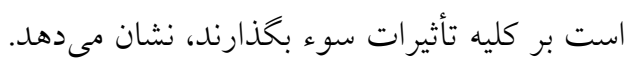

بابونه كاوى (Tanacetum parthenium) اين كياه در اكثر نواحى ايران بويزه استانهاى كيلان،

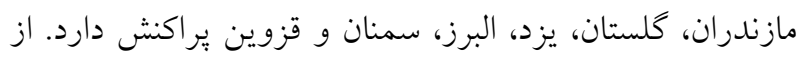

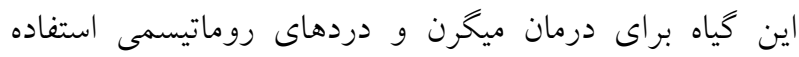

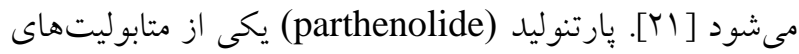

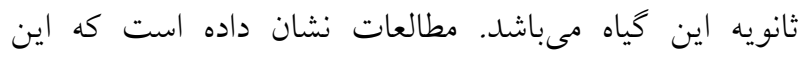

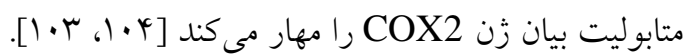

\section{Curcuma longa}

خود اين كونه در ايران وجود ندارد. اما از اعضاى جنس آن دو كونه زدو Curcuma zedoaria و زردجيوبه Curcuma domestica

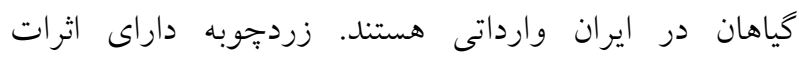

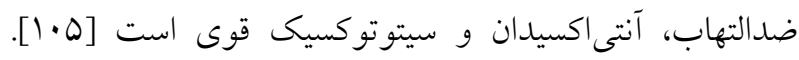

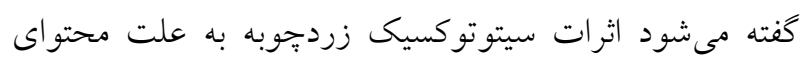

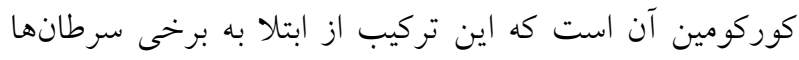
بخصوص سرطان كولون جلو كيرى مى كند. همجنين كوركومين

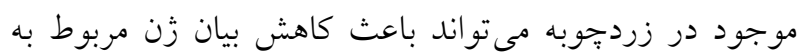

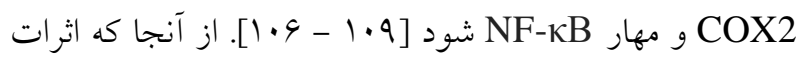

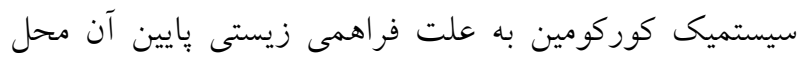

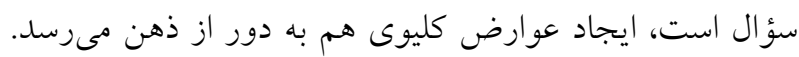

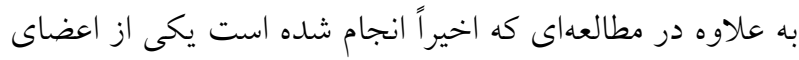

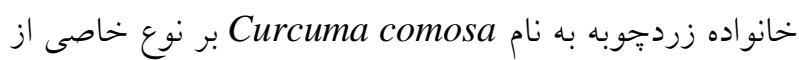

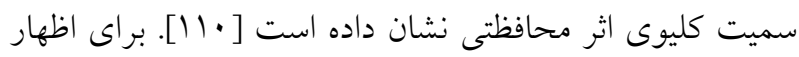

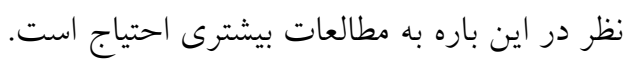

\section{كندر (Boswellia serrata)}

خود كياه كندر درختجهاى است كه گم رزين (صمغ)

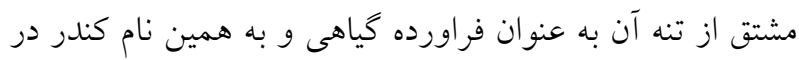

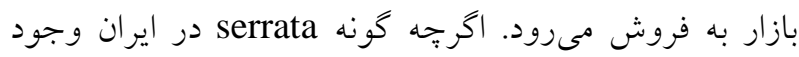
ندارد اما از اعضاى جنس آن Boswellia carteri در استان كرونه

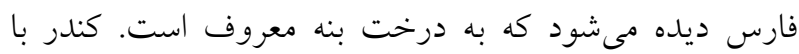

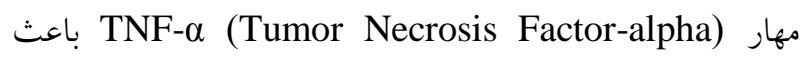
كاهش توليد COX2 و بسيارى از ديخر مدياتورهاى التهابى 
جدول شماره 1 - گياهانى كه ممكن است بر كليه تأثيرات سوء بخذارند.

\begin{tabular}{|c|c|c|c|}
\hline عارضه كليوى گياه & كاربرد گياه & 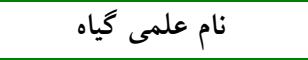 & نام فارسى گياه \\
\hline 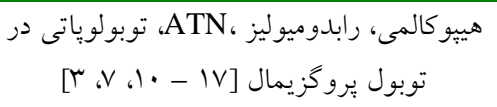 & ضدالتهاب و زخمهاى گوارشى، ضدلى & Glycyrrhiza glabra & شير بيان \\
\hline 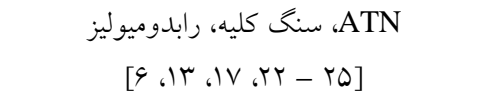 & كاهش كاشود اختلالات تنفسى و آسم، لاغرى و افزايش انرزى & Ephedra spp. & جنس افدرا \\
\hline 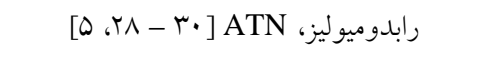 & ضدمالاريا، آنتى اكسيدان & Artemisia spp. & جنس درمنه \\
\hline احتباس ادرارى، ATN [سب، آ، IN] & توهم زا، بهبود آسم و برونشيت & Datura spp. & جنس داتوره \\
\hline رابدوميوليز، ATN ATN & دردهاى مفصلى و سياتيك، يبوست، & Colchicum autumnale & سورنجان \\
\hline 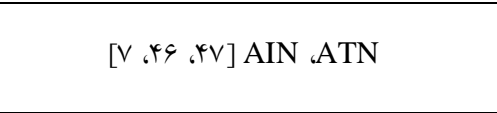 & افزايش ميل جنسى، ضدسنگ دستخاه & Tribulus terrestris & خارخاسك \\
\hline$\left[{ }^{\wedge} \wedge,{ }^{\kappa V}\right] \mathrm{ATN}$ & ملين و مسهل & Cassia obtusifolia & $\begin{array}{l}\text { اين كونه در ايران وجود } \\
\text { ندارد. }\end{array}$ \\
\hline$[11,4 q-01]$ ATN & ضدسرطان & Taxus celebia & 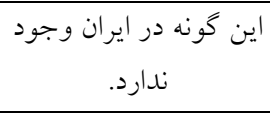 \\
\hline$[Q, \vee, I V]$ ATN & قبلاً در بيمارىهاى قلبى به عنوان مدر & Thevetia peruviana & خ خرزهره زرد \\
\hline 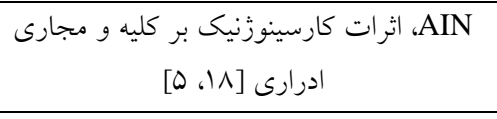 & تحريك سيستم ايمنى & Aristolochia spp. & 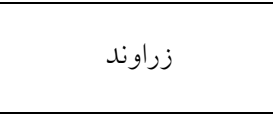 \\
\hline 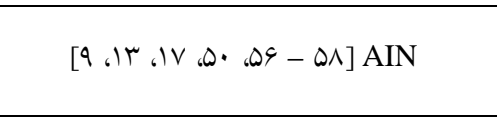 & مشكلات التهابى مانند آرتريت و التهاب & Uncaria tomentosa & ينجه كربه \\
\hline$[0, v]$ AIN & كاهش تب، بهبود درد روماتيسم، بهبود & Salix spp. & جنس بيد \\
\hline$[$ IV . $09,9 \cdot]$ AIN & بهبود عملكرد جنسى & pausinystalia yohimbe & يوهمبه \\
\hline$[థ]$ AIN & ملين، ضدالتهاب، ترميم كننده يوست & Aloe vera & 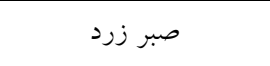 \\
\hline سنگ كليه [9V، 99، 11، 9] & جلو گيرى و درمان عفونتهاى مجارى & $\begin{array}{l}\text { Vaccinium } \\
\text { macrocarpon }\end{array}$ & كرن برى \\
\hline سنگ كليه [99، 91] & مسهل و ملين & Rumex spp. & جنس ترشك \\
\hline رابدوميوليز [VQ & ماده مخدر و توهمزا & Cannabis sativa & ماريجوانا، شاهدانه، \\
\hline ] ابدوميوليز [IV] & كاهش كلسترول خون و بهبود مشكلات & Commiphora mukul & $\begin{array}{l}\text { اين گونه در ايران وجود ندارد. } \\
\text { نارد }\end{array}$ \\
\hline 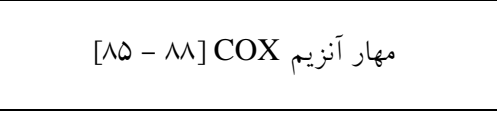 & كاهش تب و درد و بهبود مشكلات & Filipendula ulmaria & عروس جمنزار ارويايى \\
\hline مهار آنزيم COX [1 - & رفع تهوع، ضدالتهاب، ضددرد & Zingiber officinale & 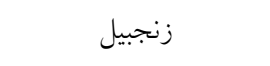 \\
\hline
\end{tabular}




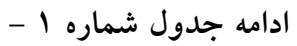

\begin{tabular}{|c|c|c|c|}
\hline عارضه كليوى گياه & كاربرد گياه & نام علمى گياه & نام فارسى گياه \\
\hline 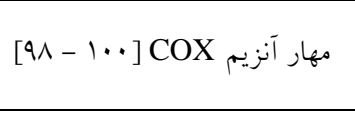 & درمان واريس، بواسير و مشكلات & $\begin{array}{c}\text { Aesculus } \\
\text { hippocastanum }\end{array}$ & شاه بلوط هندى \\
\hline مهار آنزيم COX [+1. - س.1]] & درمان ميخرن و دردهاى روماتيسمى & Tanacetum parthenium & 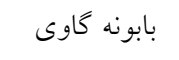 \\
\hline مهار آنزيم COX [1.9 - 1.9] & ضدالتهاب، آنتى اكسيدان & Curcuma spp & \\
\hline مهار آنزيم COX [r| - - & تنظيمكننده سيستم ايمنى، ضدالتهاب و & Boswellia serrata & 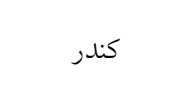 \\
\hline مهار آنزيم COX [1/9 - & آنتى اكسيدان قوى & Camellia sinensis & جاى سبز \\
\hline
\end{tabular}

ATN: Acute tubular necrosis

AIN: Acute interstitial nephritis

COX: Cyclooxygenase

فيتوشيميايى rا نمونه مختلف از كياهان ذكر شده، كه بين سال هاى •199 تا 1994 بهه بلزيك فرستاده شده بود، نشان داد كه

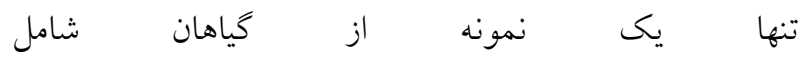
S. tetrandra

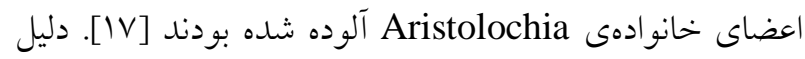
اصلى اين اشتباه، سيستم نامخذارى در طب جينى است كه نام دارد. در اين سيستم، نام گياهان از دو بخش Pin-Yin

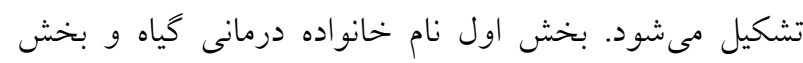

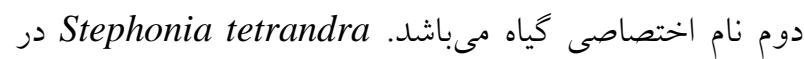
طب جينى Han Fang Ji نام دارد و احتمالاً به خاطر تشابه اسمى با نام جينى Guang Fang Ji كه مربوط به كونه Aristolochia fangchi اين نكته، كليد ماجرا و آن وجود تركيبى به نام آريستولوشيك

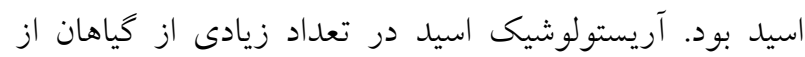
جمله گياهان جنس هاى Asarum و Braganito Aristolochia بيش از ل.ه كونه گياهى است كه در مناطق كرم مديترانه، آفريقا و آسيا وجود دارد. موارد متعددى از بيمارىهاى كليوى ناشى از مصرف گياهان حاوى اسيد آريستولوشيك در تمام

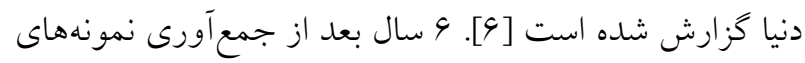
مشكل ساز حاوى گونههاى Aristolochia از بازار بلزيك،

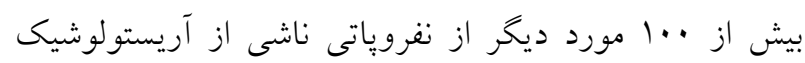

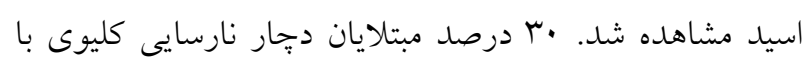

اشتباه در شناسايى، انتخاب و مخلوط شدن نمونههاى گياهى استفاده از درمانهاى گياهى به اطلاعاتى درباره كياهان آنسان

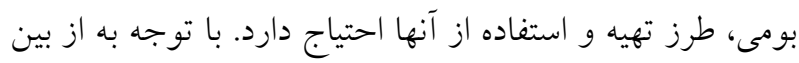

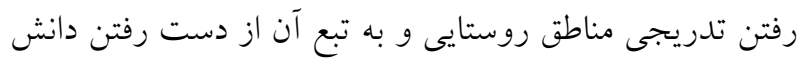

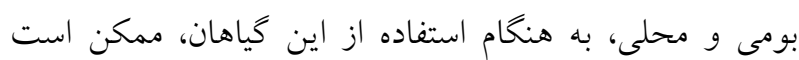

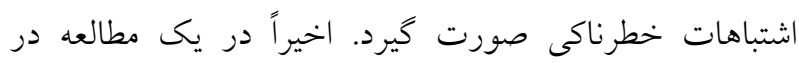

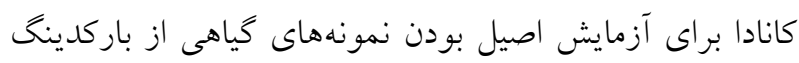

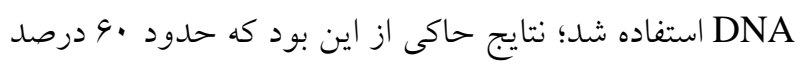

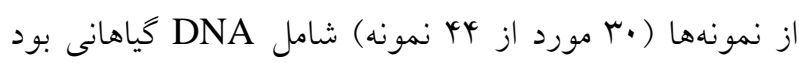

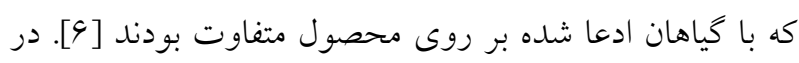
زير به دو مورد مهم اشاره مى شود كه اشتباه در شناسايى كياه به جّه نتايجى ختم شده است.

جنس زراوند و ماجراى آريستولوشيك اسيد (acistolochic (acid در اوايل سال 1999 از بروكسل 9 مورد فيبروز بافت بينابينى

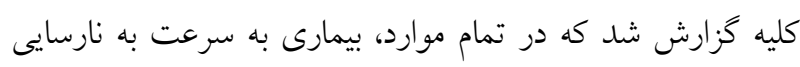
مرحله آخر كليه (ESRD; End-stage Renal Disease) رسيد. تمام اين موارد زنانى بودند كه در كلينيكى تحت رزيم

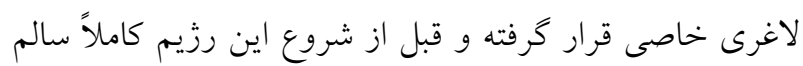

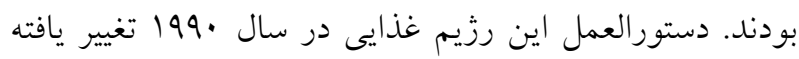
بود و به آن قرصى شامل عصاره دو كياه جينى Magnolia Stephonia tetrandra officinalis 
در استان خراسان به نام بادمجان وحشى خوانده مىشود. كونه Aristolochia bracteata

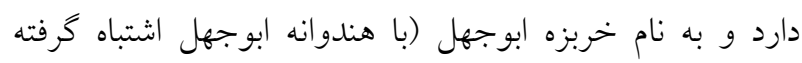

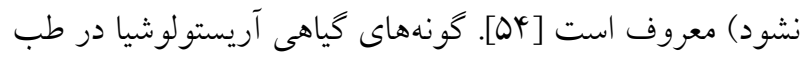

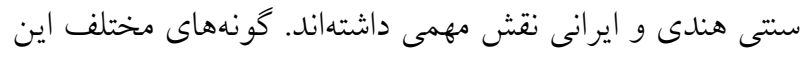

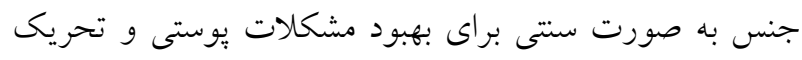

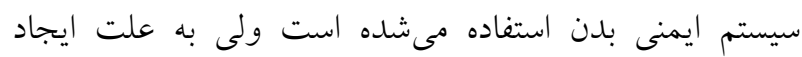

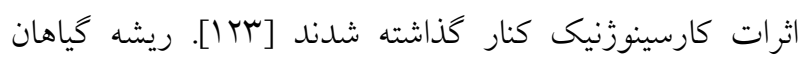

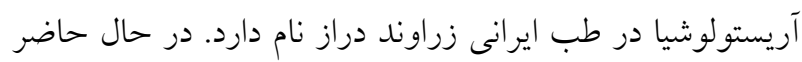

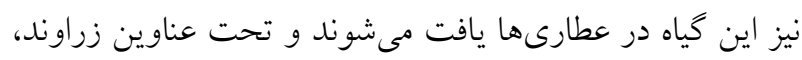

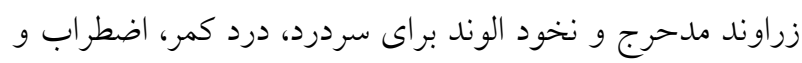

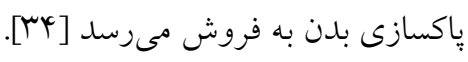

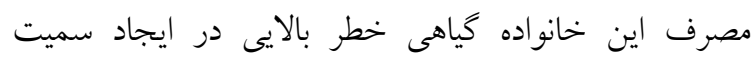

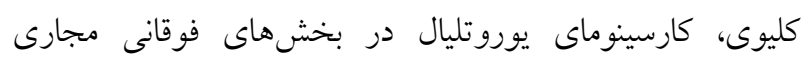

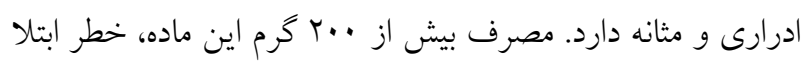

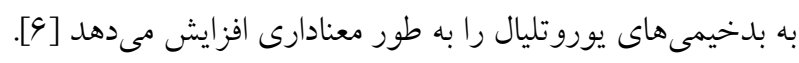

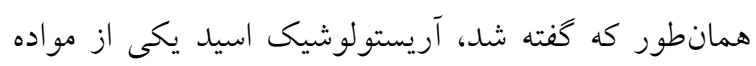

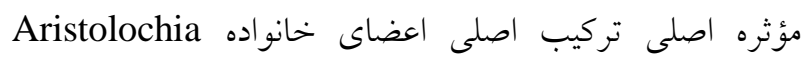

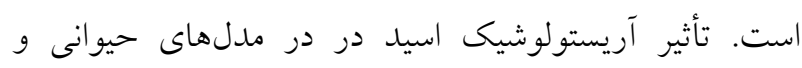

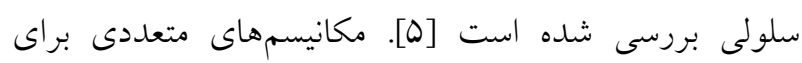
آسيبزايى آريستولوشيك اسيد به كليه مطرح شده استه است.

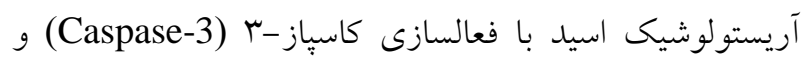

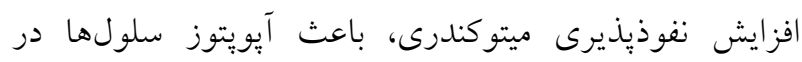

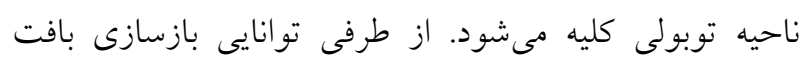

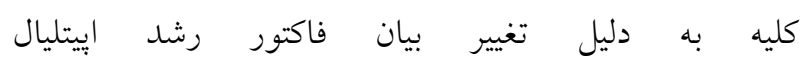
(Epidermal growth factor) عروق (Vascular endothelial growth factor) مختل مىشود [r]. فيبروبلاستهايى كه در داخل بافت وجود دارند نيز

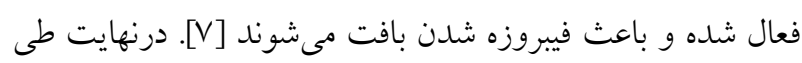

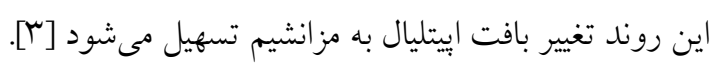

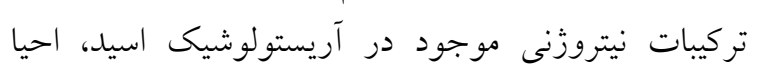

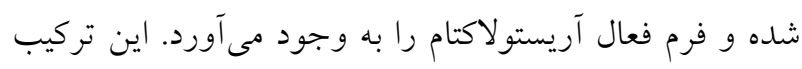

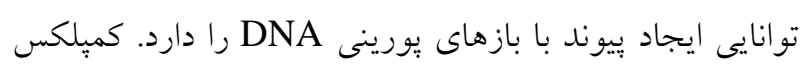
DNA- Aristolochic acid
درجه متوسط شدند و •V Vرصد تحت دياليز يا يبيوند كليه قرار

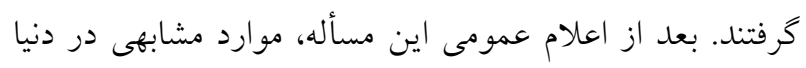

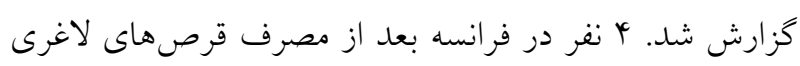
Arkomedika S. tetrandra

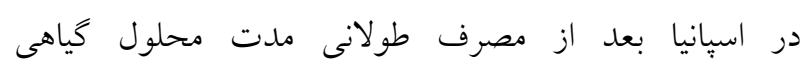

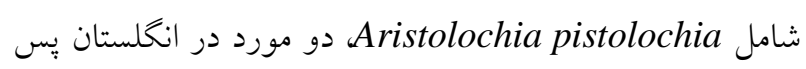
از مصرف داروى گياهى جينى به نام Mu-Tang براى درمان

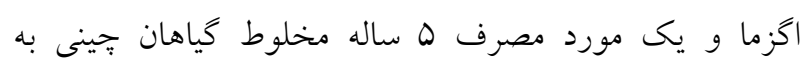

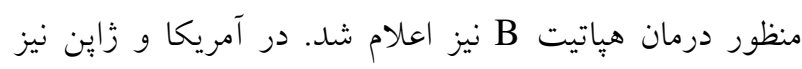

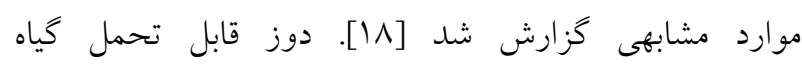

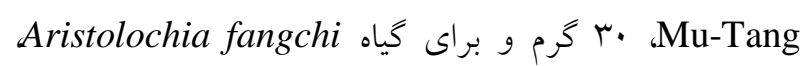

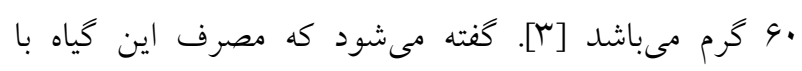

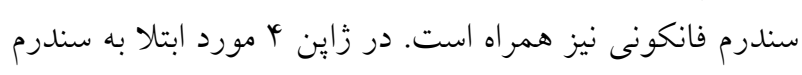

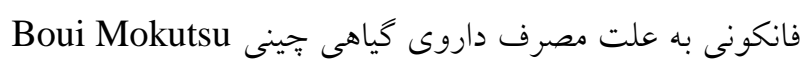

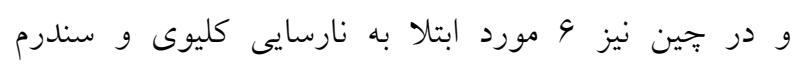

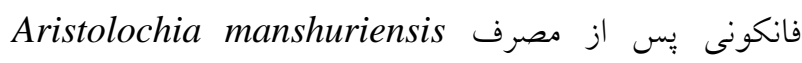
كزارش شد. هر دو گياه نام برده داراى آريستولوشيك اسيد

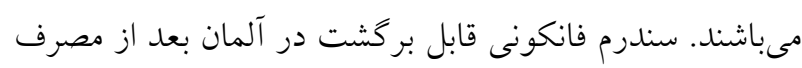

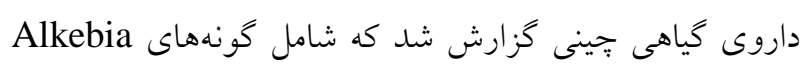

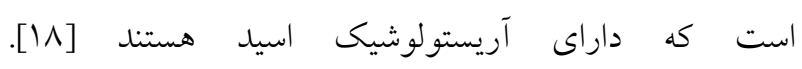

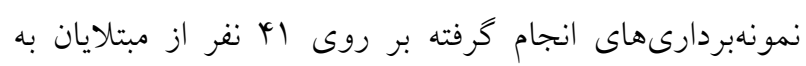

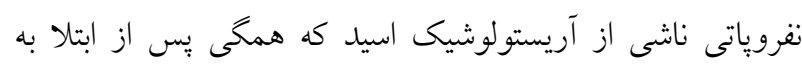

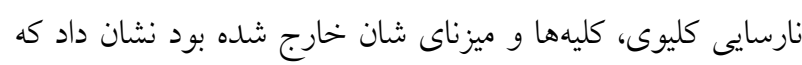

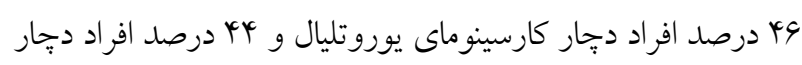

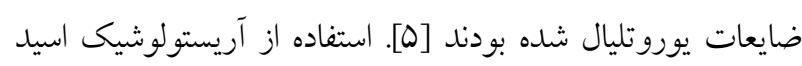

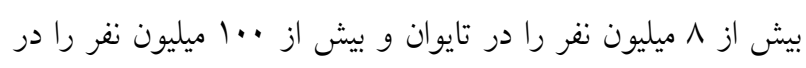

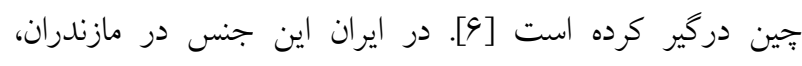

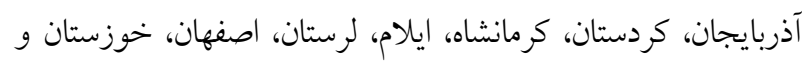

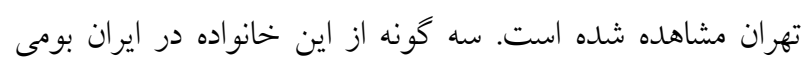

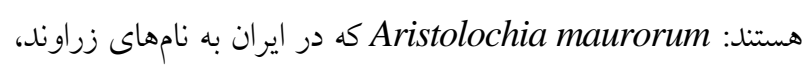
جيقى و كلاغك شناخته مى هود، Aristolochia hyrcana Savis Aristolochia olivieri Collengo 


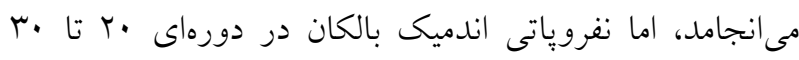

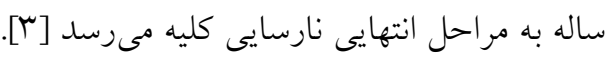

\section{Takaout Roumia كياه}

Takeout El Badia مو از دانهى يك درخت بومى با نام علمى Tamaris orientalis

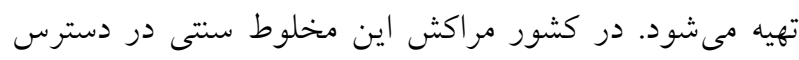

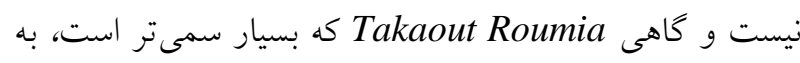

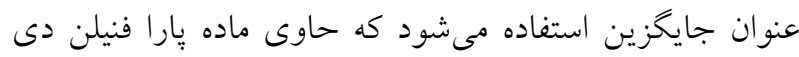

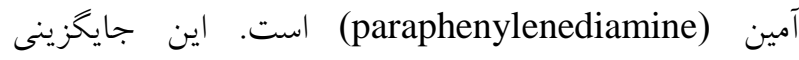

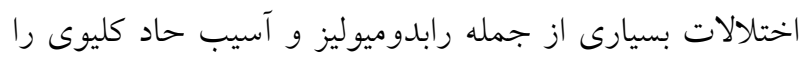

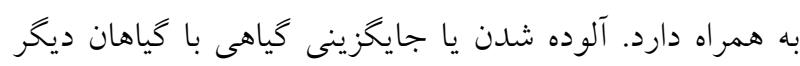

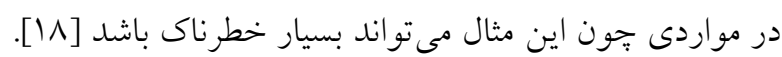

آلودگى با فلزات سنخين و داروها

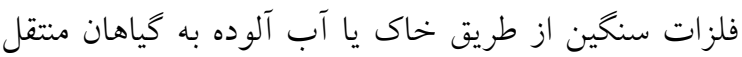
مىشوند. مسموميت با فلزات سنخين در تمام سنين به همراه

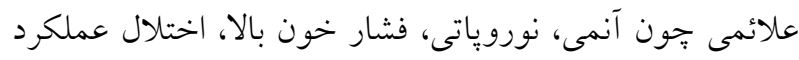

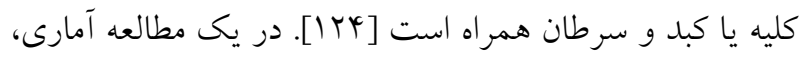

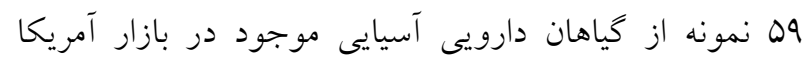

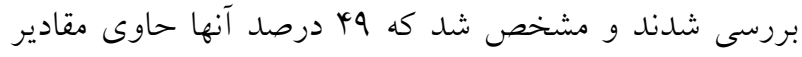

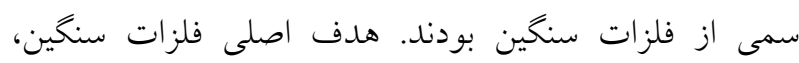

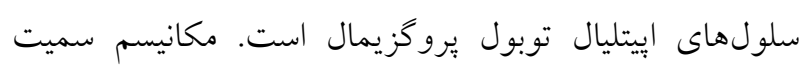

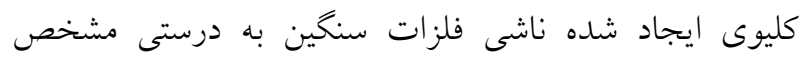

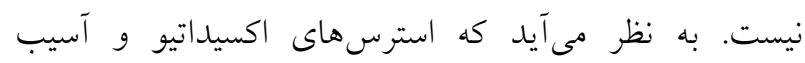

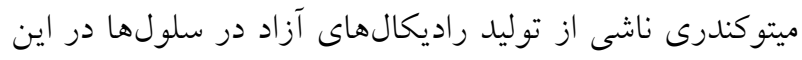

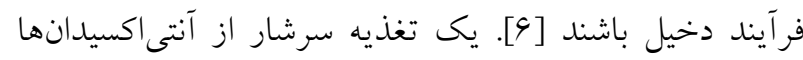

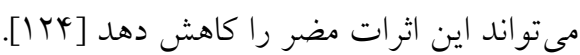

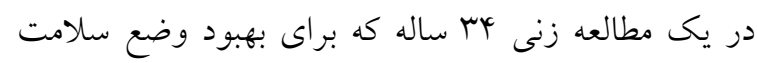

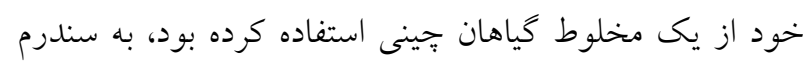

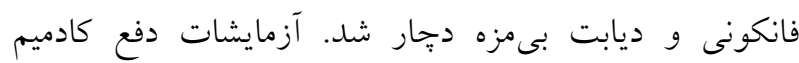

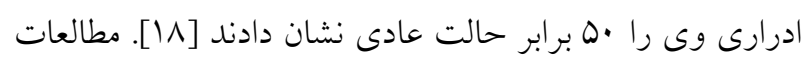

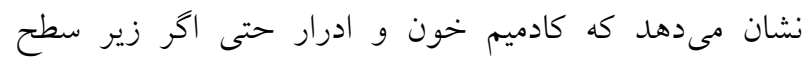

هستند كه مىتواند به كارسينوماى يوروتليال بينجامد. از مهمترين اين جهشها جهش هـ

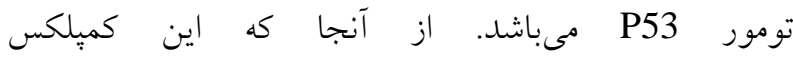
سال ها باقى مىمانند، مىتوان از DNA- Aristolochic acid آنها به عنوان يك ماركر خوب براى تشخيص بيمارى كليوى

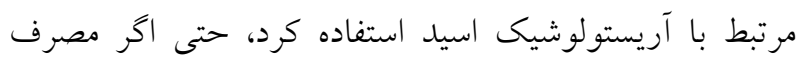

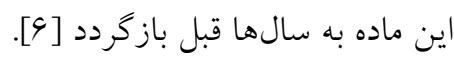
بايد در نظر داشت كه تشخيص آسيب كليوى ناشى از بال

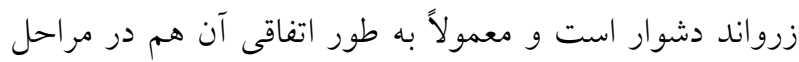

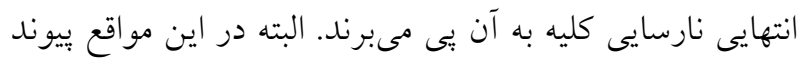

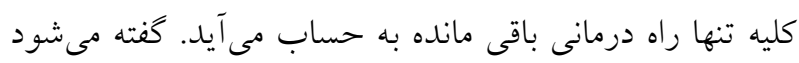

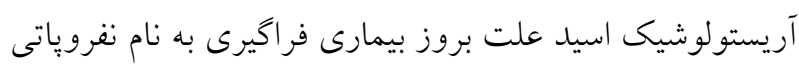
اندميك بالكان بوده است.

نفروياتى اندميك بالكان

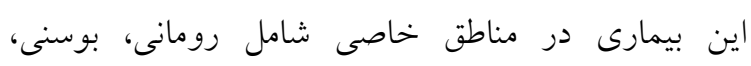

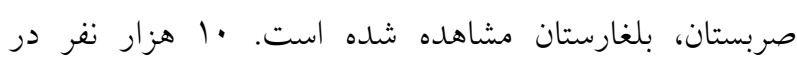
معرض خطر و ها هزار نفر بيمار مبتلا به نفروياتى بالكان بنان

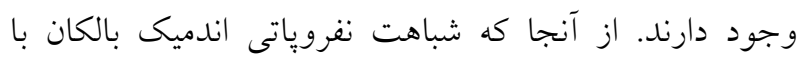

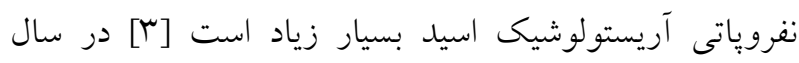

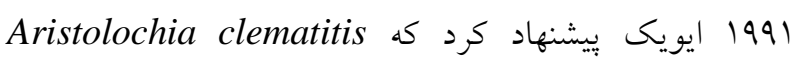

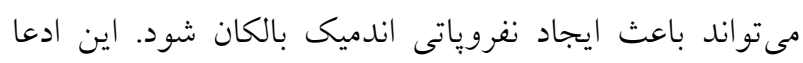

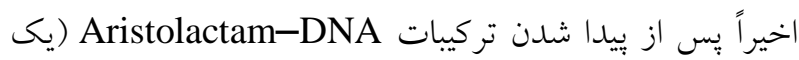
متابوليى آريستولوشيى اسيد) در بافت كليوى و تومورهاى لياى

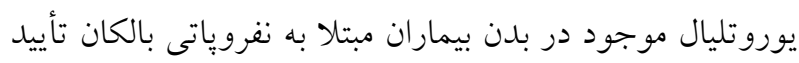

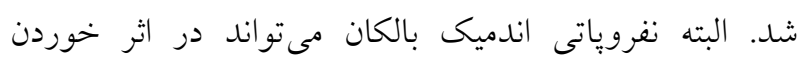

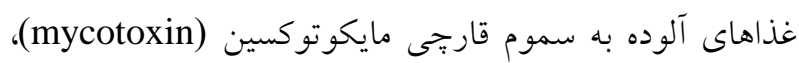

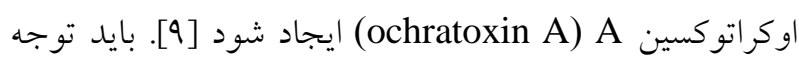
داشت كه هر دو نفروياتى بسيار به هم شبيه هستند. هر دو اين إنساد

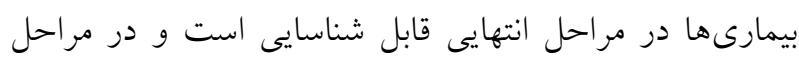

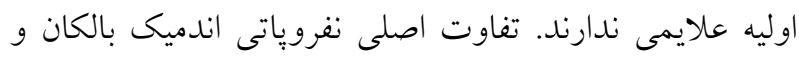

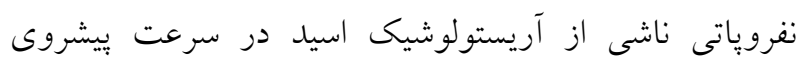

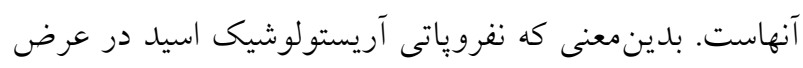

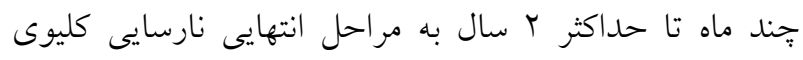


در يك مورد گزارش شده، فردى پس از مصرف قرص

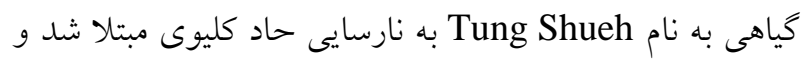

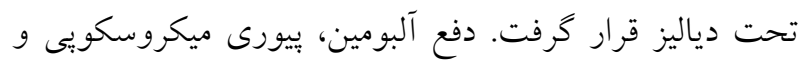

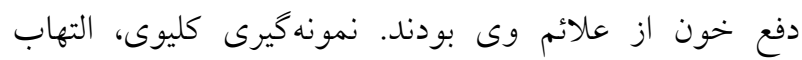

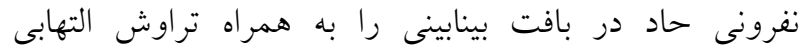

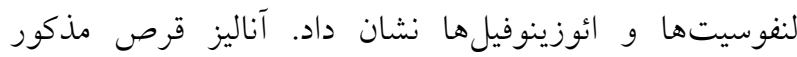
مشخص ساخت كه در آن داروهاى ديازيام و مفناميك اسيد

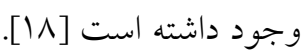

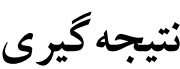

استفاده از گياهان دارويى و فرآوردههاى گياهى در نظام سلامت بسيارى از كشورهاى جهان، از جمله ايران، رواج يافته

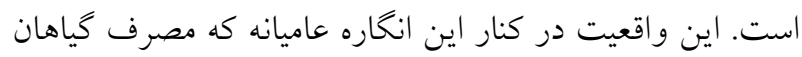

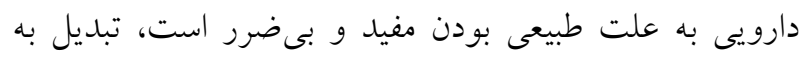

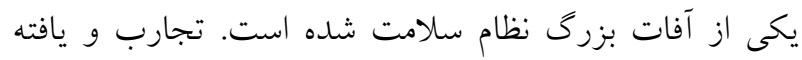

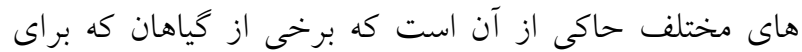

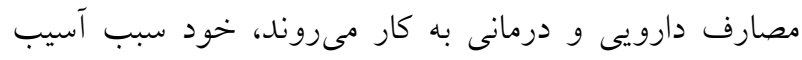
هاى جدى به كليه مىشوند و يا امراض كليوى را تشديد مى بـ

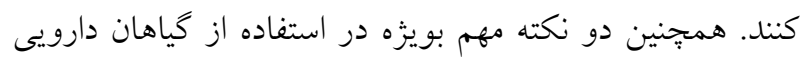

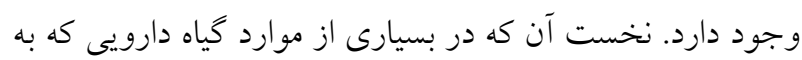

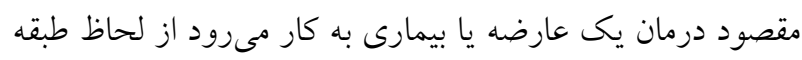

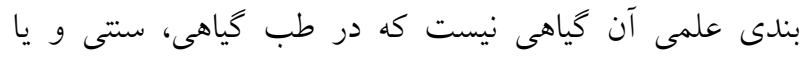
فولكلور بدان نيت استفاده شده است. دوم اينكه در بسيارى

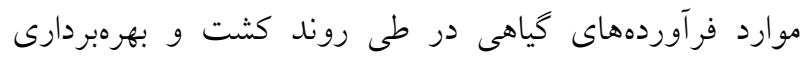

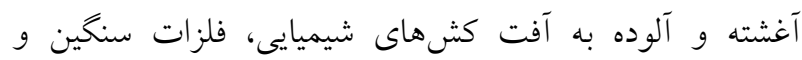

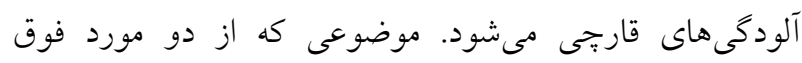

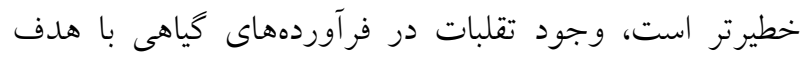

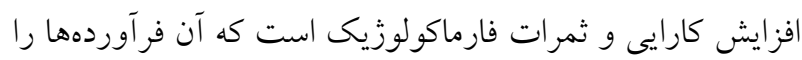

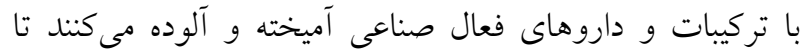
بيمار اثربخشى فراورده مصرفى را باور كند. تمامى اين موارد

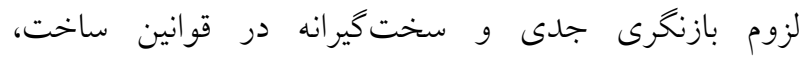

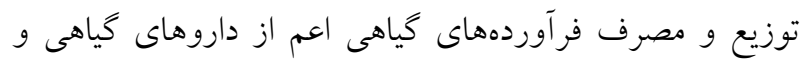

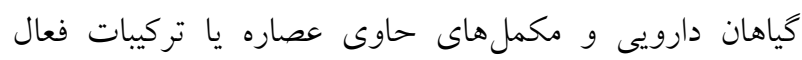

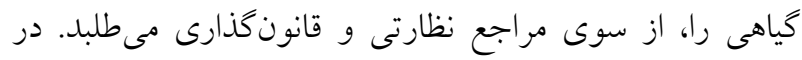

آستانه باشد، خطر ابتلا به بيمارىهاى كليوى و دفع آلبومين را افزايش مى دهد [ITOC] سرب از ديخر فلزات سنخينى است كه مىتواند باعث

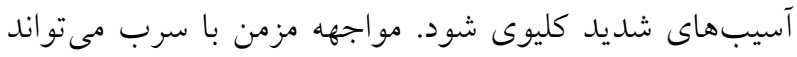

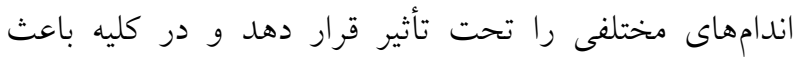
التهاب مزمن نفرونى شود. همجنين ثابت شده است كه در

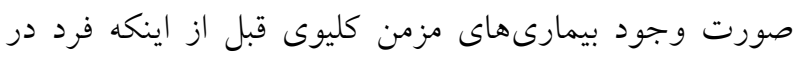

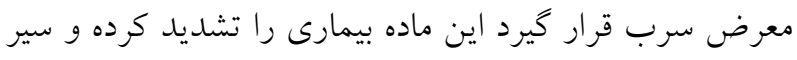

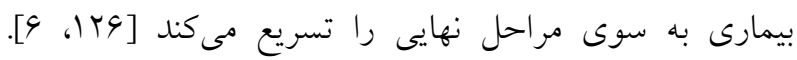

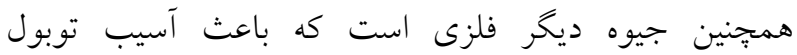

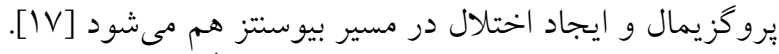

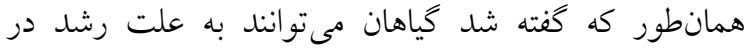

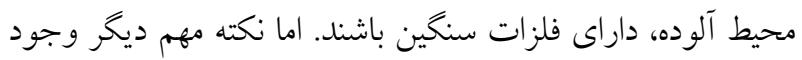

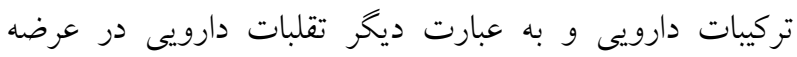
فرآوردههاى گياهى است. طبق بررسى انجام شده از بين خياهان

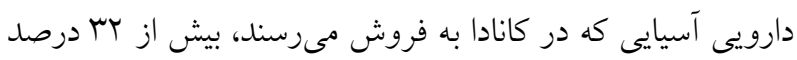

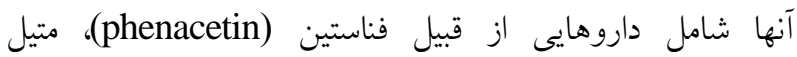

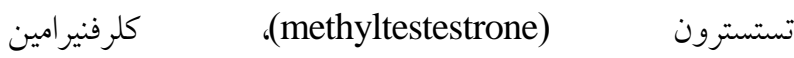

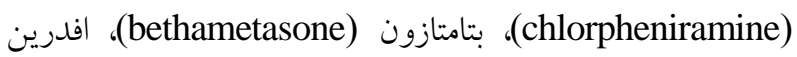

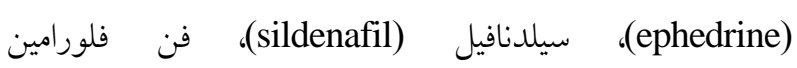
و استروئيدها (fenfluramine)

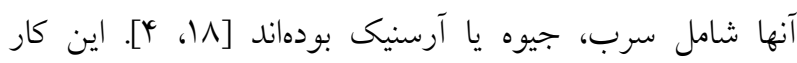

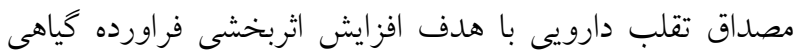
بوده است و مىتواند عوارض خطرناكى را براى مصرف كننده در

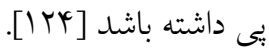

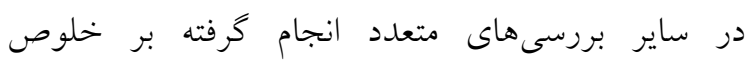

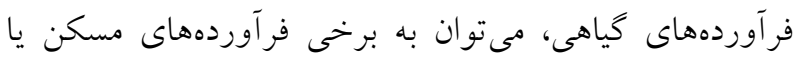

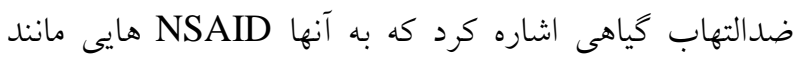

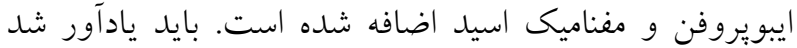
هSAID

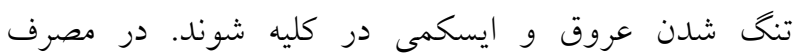

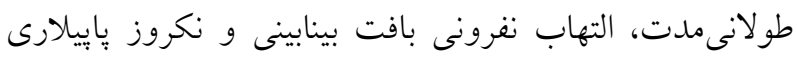
نيز مى تواند اتفاق بيافتد [IV] 


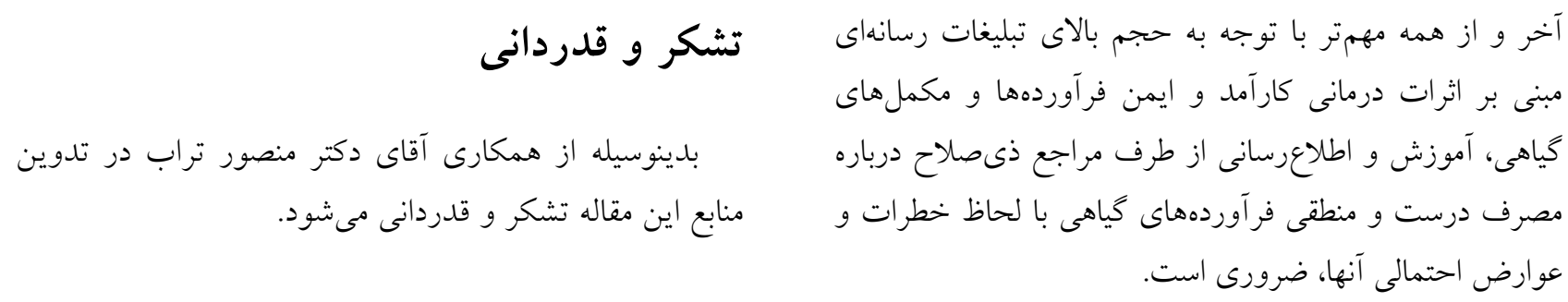

1. Ekor M. The growing use of herbal medicines: issues relating to adverse reactions and challenges in monitoring safety. Front Pharmacol. 2014; 10 (4): 177. doi: 10.3389/fphar.2013.00177.

2. Carmona F, Pereira AMS. Herbal medicines: old and new concepts, truths and misunderstandings. Revista Brasileira de Farmacognosia 2013; 23 (2): 379 - 85.

3. Jha V. Herbal medicines and chronic kidney disease. Nephrol. 2010; 15 (s2): 10 - 7.

4. Huxtable RJ. The harmful potential of herbal and other plant products. Drug Safety 1990; 5 (1): 126 - 36.

5. Nauffal $M$ and Gabardi S. Nephrotoxicity of natural products. Blood Purification 2016; 41 (13) $9-123$.

6. Marcus DM, Grollman AP. Botanical medicines - the need for new regulations. N. Engl. J. Med. 2002; 347: 2073-2076.

7. Luyckx VA and Naicker S. Acute kidney injury associated with the use of traditional medicines. Nature Reviews Nephrol. 2008; 4 (12): 664 - 671.

8. Parvaiz M, Hussain K, Khalid S, Hussnain N, Iram N, Hussain $\mathrm{Z}$ and et al. A review: Medicinal importance of Glycyrrhiza glabra L. (Fabaceae family). GJP. 2014; 8 (1): 8 - 13.

9. Singh NP and Prakash A. Nephrotoxic Potential of Herbal Drugs. JIMSA. 2011; 24 (2): 79-81.

10. zur Wiesch CS, Hahn K, Regier M, Sauer N, Beil F, Lebok $\mathrm{P}$ and et al. Hypertension with Hypokalemia in a Young Liquorice Addict.
Ultrasound in Medicine \& Biol. 2011; 37 (8): S4 S5.

11. Inuzuka $Y$, Kishimori $T$, Inoue $T$, Seki J, Nishio S, Takeda $\mathrm{S}$ and et al. Sodium Restriction in Japanese Patients Hospitalized with Acute Decompensated Heart Failure. J. Cardiac Failure 2015; 21 (10): S183.

12. Dahl NV, editor Alternative Medicine and Nephrology Series Editor: Naomi V. Dahl: Herbs and Supplements in Dialysis Patients: Panacea or Poison? Seminars in dialysis; 2001, Wiley Online Library.

13. Luyckx VA. Nephrotoxicity of alternative medicine practice. Advances in Chronic Kidney Disease 2012; 19 (3): 129 - 41.

14. Kamsu-Foguem B and Foguem C. Adverse drug reactions in some African herbal medicine: literature review and stakeholders' interview. IMR. 2014; 3 (3): 126 - 32.

15. Yasue $H$, Itoh $T$, Mizuno $Y$ and Harada $E$. Severe hypokalemia, rhabdomyolysis, muscle paralysis, and respiratory impairment in a hypertensive patient taking herbal medicines containing licorice. Internal Medicine 2007; 46 (9): $575-8$.

16. Clarke DR, Musa ARF, Fuelop $T$, PostParathyroidectomy State and Serum Albumin Levels in End-Stage Renal Disease Patients no Apparent Effect of Surgical Parathyrodectomy. Am. J. Kidney Dis. 2015; 65 (4): A1-A93.

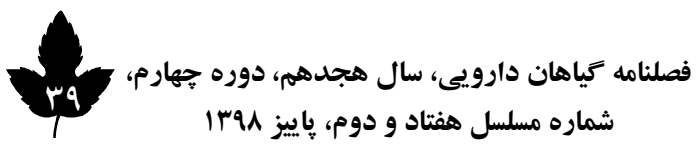


17. Gabardi S, Munz K and Ulbricht C. A review of dietary supplement-induced renal dysfunction. CJASN. 2007; 2 (4): 757 - 65.

18. Bagnis CI, Deray G, Baumelou A, Le Quintrec $\mathrm{M}$ and Vanherweghem JL. Herbs and the kidney. AJKD. 2004; 44 (1): 1 - 11.

19. Wang X, Zhang H, Chen L, Shan L,Fan G and Gao X. Liquorice, a unique "guide drug" of traditional Chinese medicine: a review of its role in drug interactions. J. Ethnopharmacol. 2013; 150 (3): 781 - 90.

20. Hou Y-C, Lin S-P and Chao P-DL. Liquorice reduced cyclosporine bioavailability by activating P-glycoprotein and CYP 3A. Food Chem. 2012; 135 (4): 2307 - 12.

21. Mozafar SM. The Herbal Encyclopedia. $1^{\text {st }}$ ed. Abej-Ebnesina-Andisheavar Press. Iran. 2016, pp: 1272-8. [in Persian].

22. Bennett $S$, Hoffman $N$ and Monga $M$. Ephedrine and guaifenesin-induced nephrolithiasis. J. Alternative \& Complementary Medicine 2004; 10 (6): 967 - 9.

23. Powell T, Hsu FF, Turk J and Hruska K. Mahuang strikes again: ephedrine nephrolithiasis. AJKD. 1998; 32 (1): 153 - 9.

24. Gabardi S, Cormier C, Cina J and Luyckx V. Renal dysfunction associated with herbal remedies and dietary supplements. Nephrology Rounds 2003; 2: 304 - 14.

25. Stahl CE, Borlongan CV, Szerlip H and Szerlip M. No pain, no gain: exercise-induced rhabdomyolysis associated with the performance enhancer herbal supplement ephedra. Medical Science Monitor 2006; 12 (9): CS81 - CS4.

26. Mozaffarian V. Indentification of Medicinal and Aromatic Plants of Iran. $1^{\text {st }}$ ed. Moaser press. Tehran 2013, pp: 1-40. [in Persian].

27. Bora KS and Sharma A. The genus Artemisia: a comprehensive review. Pharmaceutical Biology. 2011; 49 (1): 101 - 9.

28. Nguyen HT and Németh ZÉ. Sources of variability of wormwood (Artemisia absinthium L.) essential oil. J. Applied Research on Medicinal and Aromatic Plants 2016; 3 (4): 143 - 50.

29. Lachenmeier DW, Emmert J, Kuballa $T$ and Sartor G. Thujone-Cause of absinthism? Forensic science international. 2006; 158 (1): 1 - 8.

30. Weisbord SD, Soule JB and Kimmel PL. Poison on line - acute renal failure caused by oil of wormwood purchased through the Internet. NEJM. 1997; 337 (12): 825 - 7.

31. El Bazaoui A, Bellimam MA and Soulaymani A. Nine new tropane alkaloids from Datura stramonium L. identified by GC/MS. Fitoterapia 2011; 82 (2): 193 - 7.

32. Trancă SD, Szabo $R$ and Cociş $M$. Acute poisoning due to ingestion of Datura stramonium-a case report. Romanian J. Anaesthesia and Intensive Care 2017; 24 (1): 65.

33. Disel NR, Yilmaz M, Kekec $Z$ and Karanlik M. Poisoned after dinner: Dolma with datura stramonium. Turkish J. Emergency Medicine 2015; 5- 51: (1) 15.

34. Krenzelok EP. Aspects of Datura poisoning and treatment. Clinical Toxicol. 2010; 48 (2): 104 - 10.

35. Günaydın YK, Yıldız CG, Işıkoğlu V, Kokulu K, Muraçar N, Akıllı NB and et al. Datura Stramonium Poisoning: Two Case Reports. Journal of Academic Emergency Medicine Case Reports/Akademik Acil Tip Olgu Sunumlari Dergisi (Acil Tip Uzmanlari Dernegi). 2017; 8 (1): 4-6.

36. Arefi M, Barzegari N, Asgari M, Soltani S, Farhidnia $\mathrm{N}$ and Fallah F. Datura poisoning, clinical and laboratory findings. Report of five cases. Romanian J. Legal Medicine 2016; 24 (4): $308-11$.

37. Dubey P and Sanjeev O. Acute Renal Failure: A Complication of Datura Poisoning. J. Kidney. 2017; 3 (147): 2472-1220.1000147.

38. Naqvi R. Acute kidney injury from different poisonous substances. World J. Nephrol. 2017; 6 (3): 162 . 
39. Suhail S, Shakir Jamil S, Jilani $S$ and et al. Phytochemical and Pharmacological Review of Suranjan Shireen (Colchicum autumnale). Indo American Journal of Pharmaceutical Res. 2017; 7 (04): $8492-6$.

40. Klintschar M, Beham-Schmidt C, Radner H, Henning $G$ and Roll P. Colchicine poisoning by accidental ingestion of meadow saffron (Colchicum autumnale): pathological and medicolegal aspects. Forensic Science International. 1999; 106 (3): 191 - 200.

41. Brvar M, Ploj T, Kozelj G, Mozina M, Noc M and Bunc M. Case report :fatal poisoning with Colchicum autumnale. Critical Care. 2004; 8 (1): R56.

42. Brnčić N, Višković I, Perić R, Đirlić A, Vitezić $\mathrm{D}$ and Cuculić D. Accidental plant poisoning with Colchicum autumnale: report of two cases. CMJ. 2001; 42 (6): $673-5$.

43. Nagesh K, Menezes RG, Rastogi $P$, Naik N, Rasquinha JM, Senthilkumaran $\mathrm{S}$ and et al. Suicidal plant poisoning with Colchicum autumnale. J. Forensic and Legal Medicine 2011; 18 (6): 285 - 7.

44. Wollersen H, Erdmann F, Risse $M$ and Dettmeyer R. Accidental fatal ingestion of colchicine-containing leaves-toxicological and histological findings. Legal Medicine 2009; 11: S498 - S9.

45. Ryan M, Lazar I, Nadasdy GM, Nadasdy T and Satoskar AA. Acute kidney injury and hyperbilirubinemia in a young male after ingestion of Tribulus terrestris. Clinical Nephrol. 2015; 83 (3): $177-83$.

46. Talasaz AH, Abbasi M-R, Abkhiz $S$ and Dashti-Khavidaki S. Tribulus terrestris-induced severe nephrotoxicity in a young healthy male. NDT. 2010; 25 (11): 3792 - 3.

47. Yagi S, El Tigani S and Adam S. Toxicity of Senna obtusifolia fresh and fermented leaves (kawal), Senna alata leaves and some products from Senna alata on rats. Phytotherapy Res. 1998; 12 (5): $324-30$.

48. Vanderperren B, Rizzo $M$, Angenot L, Haufroid V, Jadoul M and Hantson P. Acute liver failure with renal impairment related to the abuse of senna anthraquinone glycosides. Annals of Pharmacotherapy 2005; 39 (7 - 8): 1353 - 7.

49. Cho BS, Kim SD, Choi YM and Kang HH. School urinalysis screening in Korea: Prevalence of chronic renal disease. Pediatr. Nephrol. 2001; 16: 1126-8.

50.Voss, D. Complementary medicines in predialysis patients. Nephrology 2005, 10: S201S203.

51. Tewari I, Sood S and Gupta GL. Toxicities of herbal medicines: use with precautions. JPR. 2014; $4(02)$.

52. Malik S, Cusidó RM, Mirjalili MH ,Moyano E, Palazón $\mathrm{J}$ and Bonfill $\mathrm{M}$. Production of the anticancer drug taxol in Taxus baccata suspension cultures: a review. Process Biochem. 2011; 46 (1): $23-34$.

53. Bandara $\mathrm{V}$, Weinstein SA, White $\mathrm{J}$ and Eddleston M. A review of the natural history, toxinology, diagnosis and clinical management of Nerium oleander (common oleander) and Thevetia peruviana (yellow oleander) poisoning. Toxicon. 2010; 56 (3): 273 - 81.

54. Ardalan MR, Khodaie L, Nasri $H$ and Jouyban A. Herbs and hazards: risk of aristolochic acid nephropathy in Iran. IJKD. 2015; 9 (1): 14 - 7.

55. Valerio LG and Gonzales GF. Toxicological aspects of the South American herbs cat's claw (Uncaria tomentosa) and maca (Lepidium meyenii). Toxicological Reviews 2005; 24 (1): 11 - 35.

56. Singh $N$ and Prakash A. Herbal drugs and acute renal injury. Medicine Update 2008; 18: 150 - 5.

57. Combest W, Newton M, Combest $A$ and Kosier JH. Effects of herbal supplements on the kidney. Urologic Nursing 2005; 25 (5): 381.

58. Hilepo JN, Bellucci AG and Mossey RT. Acute renal failure caused by 'cat's claw'herbal

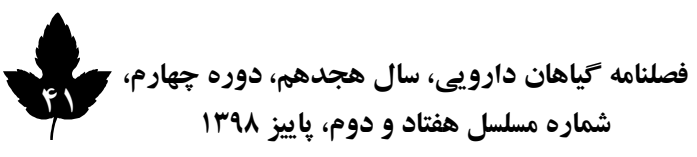


remedy in a patient with systemic lupus erythematosus. Nephron. 1997; 77 (3): 361.

59. Yakubu MT, Bilbis LS, Lawal $M$ and Akanji MA. Evaluation of selected parameters of rat liver and kidney function following repeated administration of yohimbine. Biokemistri 2003; 15 (2): $50-6$.

60. Eweka A, Om'Iniabohs $\mathrm{F}$ and Momodu O. The histological effects of mixed diet containing Pausinystalia yohimbe ground stem bark on the kidney of adult Wistar rats (Rattus norvegicus). Biol. Med. 2010; 2 (1): 30-36.

61. Bahekar A, Ingle R and Kendre V. Efficacy of fungicides and bioagent against fungal pathogens of Aloe vera. IJCS. 2017; 5 (4): 1540 - 3.

62. Agarwal N, Sadhukhan P, Saha S and Sil PC. Therapeutic Insights against oxidative stress induced diabetic nephropathy: a review. $J$. Autoimmune Disorders 2015; 1 (1). doi: 10.21767/2471-8513.

63. Ekor M. Nephrotoxicity and Nephroprotective Potential of African Medicinal Plants in: Kuete V. Toxicological Survey of African Medicinal Plants. Elsevier. 2014, pp: 357 - 93.

64. Ramachandraiahgari Y, Madhavi R, Somesula SR, Adi PJ, Mannur IS, Enamala $M$ and et al. Protective Role of Ethanolic Extract of Aloe vera Antioxidant Properties on Liver and Kidney of Streptozotocin-Induced Diabetic Rats. DJNB. 2012; 7 (1): 175-184.

65. Dangi N, Gyanwali M, Gyanwali P, Sapkota H, Pandey A and Shrestha A. Evaluation of aloe vera leaves extract in streptozotocin-induced diabetic nephropathy in rat. J. Chitwan Medical College 2017; 5 (4): 55 - 63.

66. Kessler T, Jansen B and Hesse A. Effect of blackcurrant-, cranberry-and plum juice consumption on risk factors associated with kidney stone formation. European J. Clinical Nutrition 2002; 56 (10): 1020.

67. Gettman MT, Ogan K, Brinkley LJ, Adams-Huet

B, Pak CY and Pearle MS. Effect of cranberry juice consumption on urinary stone risk factors. The Journal of Urology 2005; 174 (2): 590 - 4.

68. Vasas A, Orbán-Gyapai $O$ and Hohmann J. The Genus Rumex: Review of traditional uses, phytochemistry and pharmacology. $J$. Ethnopharmacol. 2015; 175: 198 - 228.

69. Islam R, Mamat Y, Ismayil I, Yan M, Kadir M, Abdugheny A and et al. Toxicity of anthraquinones: differential effects of rumex seed extracts on rat organ weights and biochemical and haematological parameters. Phytotherapy Res. 2015; 29 (5): 777 - 84.

70. Zager RA. Rhabdomyolysis and myohemoglobinuric acute renal failure. Kidney International. 1996; 49 (2): $314-26$.

71. Zimmerman JL and Shen MC. Rhabdomyolysis. Chest. 2013; 144 (3): 1058 - 65.

72. Vanholder R, Sever MS, Erek E and Lameire N. Rhabdomyolysis. JASN. 2000; 11 (8): 1553 - 61.

73. Vaziri ND, Thomas R, Sterling M, Seiff K, Pahl MV, Davila $J$ and et al. Toxicity with intravenous injection of crude marijuana extract. Clinical Toxicol. 1981; 18 (3): 353 - 66.

74. Brandenburg $D$ and Wernick $R$. Intravenous marijuana syndrome. Western J. Medicine 1986; 145 (1): 94.

75. Bohatyrewicz M, Urasinska E, Rozanski J, Ciechanowski K. Membranous glomerulonephritis may be associated with heavy marijuana abuse. Transplant Proc. 2007; 39 (10): 3054-6.

76. Argamany JR, Reveles KR, Duhon B. Synthetic cannabinoid hyperemesis resulting in rhabdomyolysis and acute renal failure. The American J. Emergency Medicine 2016; 34 (4): 765. e1-. e2.

77. Zhao A, Tan M, Maung A, Salifu M and Mallappallil M. Rhabdomyolysis and acute kidney injury requiring dialysis as a result of concomitant use of atypical neuroleptics and synthetic cannabinoids. Case Reports in Nephrol. 2015; 2015.

78. Durand D, Delgado LL, Parra-Pellot DMdl and Nichols-Vinueza D. Psychosis and severe 
rhabdomyolysis associated with synthetic cannabinoid use: a case report. Clinical Schizophrenia \& Related Psychoses 2013; 8 (4): $205-8$.

79. Paul ABM, Simms L, Paul AE, Schmidseder C, Mahesan AA and Yorke J. Not safe for consumption :synthetic cannabinoids causing fatal acute rhabdomyolysis in two young men. IJCRI. 2016; 7 (7): 431 - 5.

80. Ulbricht C, Basch E, Szapary P, Hammerness $\mathrm{P}$, Axentsev $\mathrm{S}$, Boon $\mathrm{H}$ and et al. Guggul for hyperlipidemia :a review by the Natural Standard Research Collaboration. Complementary therapies in Medicine 2005; 13 (4): 279 - 90.

81. Singh BB, Mishra LC, Vinjamury SP and Aquilina N. The effectiveness of Commiphora mukul for osteoarthritis of the knee: an outcomes study. Alternative Therapies in Health and Medicine 2003; 9 (3): 74.

82. Shen T, Li G-H, Wang X-N and Lou H-X. The genus Commiphora: a review of its traditional uses, phytochemistry and pharmacology. $J$. Ethnopharmacol. 2012; 142 (2): 319 - 30.

83. Zhang X, Donnan PT, Bell S, Guthrie B. Nonsteroidal anti-inflammatory drug induced acute kidney injury in the community dwelling general population and people with chronic kidney disease: systematic review and meta-analysis. BMC nephrology. 2017;18(1):256.

84. Brunton L, Knollman B and Hilal-Dandan R. Goodman and Gilman's The Pharmacological Basis of Therapeutics, 13th Edition: McGraw-Hill Education. 2017.

85. Papp I, Simándi B, Blazics B, Alberti Á, Héthelyi É, Szőke É and et al. Monitoring volatile and non-volatile salicylates in Filipendula ulmaria by different chromatographic techniques. Chromatographia 2008; 68 (1): 125 - 9.

86. Blazics B, Papp I, Kéry Á. LC-MS qualitative analysis and simultaneous determination of six Filipendula salicylates with two standards. Chromatographia 2010; 71 (1): 61 - 7.
87. Denev P, Kratchanova M, Ciz M, Lojek A, Vasicek O, Blazheva D and et al. Antioxidant, antimicrobial and neutrophil-modulating activities of herb extracts. Acta Biochimica Polonica 2014; 61 (2): 359-367.

88. Harbourne N, Marete E, Jacquier JC and O'Riordan D. Effect of drying methods on the phenolic constituents of meadowsweet (Filipendula ulmaria) and willow (Salix alba). LWT-Food Science and Technol. 2009; 42 (9): 1468 - 73.

89. Ali BH, Blunden G, Tanira MO and Nemmar A. Some phytochemical, pharmacological and toxicological properties of ginger (Zingiber officinale Roscoe): a review of recent research. Food and chemical Toxicol. 2008; 46 (2): 409 - 20. 90. Tjendraputra E, Tran VH, Liu-Brennan D, Roufogalis BD and Duke CC. Effect of ginger constituents and synthetic analogues on cyclooxygenase-2 enzyme in intact cells. Bioorganic Chem. 2001; 29 (3): 156 - 63.

91. Van Breemen RB, Tao $\mathrm{Y}$ and $\mathrm{Li} \mathrm{W}$. Cyclooxygenase-2 inhibitors in ginger (Zingiber officinale). Fitoterapia 2011; 82 (1): 38 - 43.

92. Habib SHM, Makpol S, Hamid NAA, Das S, Ngah WZW and Yusof YAM. Ginger extract (Zingiber officinale) has anti-cancer and antiinflammatory effects on ethionine-induced hepatoma rats. Clinics. 2008; 63 (6): 807 - 13.

93. Stoilova I, Krastanov A, Stoyanova A, Denev $\mathrm{P}$, Gargova S .Antioxidant activity of a ginger extract (Zingiber officinale). Food Chem. 2007; 102 (3): 764 - 70.

94. Ramudu SK, Korivi M, Kesireddy N, Lee L-C, Cheng I-S, Kuo C-H and et al. Nephro-protective effects of a ginger extract on cytosolic and mitochondrial enzymes against streptozotocin (STZ)-induced diabetic complications in rats. Chin. J. Physiol. 2011; 54 (2): 79 - 86.

95. Almarshad HA, Tantawy AAE-H and Alenazi TA. The Nephroprotective Effect of Zingiber Officinale Extract against Azathioprine-Induced Renal Damage: An Experimental

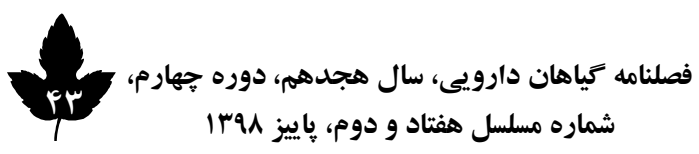


Histopathological Study. Aljouf University Medical J. 2015; 300 (3803): 1 - 8.

96. Ramudu SK, Korivi M, Kesireddy N, Chen C$\mathrm{Y}$, Kuo $\mathrm{CH}$ and Kesireddy SR. Ginger feeding protects against renal oxidative damage caused by alcohol consumption in rats. J. Renal Nutrition 2011; 21 (3): 263-70.

97. Snow A, Halpenny D, McNeill G and Torreggiani WC. Life-threatening rupture of a renal angiomyolipoma in a patient taking over-thecounter horse chestnut seed extract. J. Emergency Medicine 2012; 43 (6): e401-e3.

98. Wang T, Jiang N, Han B, Liu W, Liu T, Fu Fand et al. Escin attenuates cerebral edema induced by acute omethoate poisoning. Toxicology Mechanisms and Methods 2011; 21 (5): 400-5.

99. Wang $\mathrm{H}$, Zhang L, Jiang N, Wang Z, Chong Y and Fu F. Anti-inflammatory effects of escin are correlated with the glucocorticoid receptor/NF- $\kappa \mathrm{B}$ signaling pathway, but not the COX/PGF $2 \alpha$ signaling pathway. Experimental and Therapeutic Medicine 2013; 6 (2): 419-22.

100. Li M, Lu C, Zhang L, Zhang J, Du Y, Duan $S$ and et al. Oral administration of escin inhibits acute inflammation and reduces intestinal mucosal injury in animal models. Evidence-Based Complementary and Alternative Medicine 2015; 2015; doi: 10.1155/2015/503617.

101. Grasso A and Corvaglia E. Two cases of suspected toxic tubulonephrosis due to Escine. Gazz. Med. It. 1976; 135: 581-4.

102. Baibado JT and Cheung HY. Seed Extract of Horse Chestnut (Aesculus hippocastanum L.) as Effective Medication for Chronic Venous Insufficiency and Other Health Benefits. Hong Kong Pharmaceutical Journal 2010; 17(4): 156162.

103. Sur R, Martin $K$, Liebel F, Lyte $P$, Shapiro $S$ and Southall M. Anti-inflammatory activity of parthenolide-depleted Feverfew (Tanacetum parthenium). Inflammopharmacol. 2009; 17 (1): 42-9.
104. Smolinski AT and Pestka JJ. Modulation of lipopolysaccharide-induced proinflammatory cytokine production in vitro and in vivo by the herbal constituents apigenin (chamomile), ginsenoside $\mathrm{Rb} 1$ (ginseng) and parthenolide (feverfew). Food and Chemical Toxicol. 2003; 41 (10): 1381-90.

105. Akram M, Shahab-Uddin AA, Usmanghani K, Hannan A, Mohiuddin E and Asif M. Curcuma longa and curcumin: a review article. Rom. J. Biol. Plant. Biol. 2010; 55 (2): 65-70.

106. Shishodia $S$, Potdar $P$, Gairola $C G$ and Aggarwal BB. Curcumin (diferuloylmethane) down-regulates cigarette smoke-induced NF- $\mathrm{KB}$ activation through inhibition of $\mathrm{I} \kappa \mathrm{B} \alpha$ kinase in human lung epithelial cells: correlation with suppression of COX-2, MMP-9 and cyclin D1. Carcinogenesis 2003; 24 (7): 1269-79.

107. Plummer SM, Holloway KA, Manson MM, Munks RJ, Kaptein A, Farrow $\mathrm{S}$ and et al. Inhibition of cyclo-oxygenase 2 expression in colon cells by the chemopreventive agent curcumin involves inhibition of $\mathrm{NF}-\kappa \mathrm{B}$ activation via the NIK/IKK signalling complex. Oncogene. 1999; 18 (44): 6013.

108. Binion DG, Otterson $M F$ and Rafiee $P$. Curcumin inhibits VEGF-mediated angiogenesis in human intestinal microvascular endothelial cells through COX-2 and MAPK inhibition. Gut. 2008; 57 (11): 1509-17.

109. Lev-Ari S, Starr A, Vexler A, Karaush V, Loew V, Greif $J$ and et al. Inhibition of pancreatic and lung adenocarcinoma cell survival by curcumin is associated with increased apoptosis, down-regulation of COX-2 and EGFR and inhibition of Erk1/2 activity. Anticancer Res. 2006; 26 (6B): 4423-30.

110. Chuncharunee A, Habuddha V and Chuncharunee A. Curcuma comosa ameliorates cisplatin-induced nephrotoxicity: COX-2 expression and ultrastructure changes. J. Medicinal Plants Res. 2016; 10 (34): 595-602. 
111. Gayathri B, Manjula $N$, Vinaykumar $K$, Lakshmi B and Balakrishnan A. Pure compound from Boswellia serrata extract exhibits antiinflammatory property in human PBMCs and mouse macrophages through inhibition of TNF $\alpha$, IL-1 $\beta$, NO and MAP kinases. International Immunopharmacol. 2007; 7 (4): 473-82.

112. Singh $D$, Gupta $R$ and Saraf SA. Herbs-are they safe enough? An overview. Critical Reviews in Food Science and Nutrition 2012; 52 (10): 876-98.

113. Balachandran $\mathrm{P}$ and Govindarajan $\mathrm{R}$. Ayurvedic drug discovery. Expert Opinion on Drug Discovery 2007; 2 (12): 1631-52.

114. Du Z, Liu Z, Ning Z, Liu Y, Song Z, Wang $\mathrm{C}$ and et al. Prospects of boswellic acids as potential pharmaceutics. Planta Medica 2015; 81 (04): 259-71.

115. Nakagawa $T$ and Yokozawa $T$. Direct scavenging of nitric oxide and superoxide by green tea. Food and Chemical Toxicol. 2002; 40 (12): 1745-50.

116. Yokozawa T, Noh JS and Park CH. Green tea polyphenols for the protection against renal damage caused by oxidative stress. EvidenceBased Complementary and Alternative Medicine. 2012; doi: 10.1155/2012/845917.

117. Crespy V and Williamson G. A review of the health effects of green tea catechins in in vivo animal models. The Journal of Nutrition 2004; 134 (12): 3431S-40S.

118. Namita $P$, Mukesh $R$ and Vijay KJ. Camellia sinensis (green tea): A review. Global $J$. Pharmacol. 2012; 6 (2): 52-9.

119. Moseley VR, Morris J, Knackstedt RW and Wargovich MJ. Green tea polyphenol epigallocatechin 3-gallate, contributes to the degradation of DNMT3A and HDAC3 in HCT 116 human colon cancer cells. Anticancer Res. 2013; 33 (12): 5325-33.

120. Singh $T$ and Katiyar SK. Green tea catechins reduce invasive potential of human melanoma cells by targeting COX-2, PGE2 receptors and epithelial-to-mesenchymal transition. PLOS ONE 2011; 6 (10): e25224.

121. Ahmed $S$, Rahman A, Hasnain A, Lalonde M, Goldberg VM and Haqqi TM. Green tea polyphenol epigallocatechin-3-gallate inhibits the IL-1 $\beta$-induced activity and expression of cyclooxygenase- 2 and nitric oxide synthase- 2 in human chondrocytes. Free Radical Biology and Medicine 2002; 33 (8): 1097-105.

122. Khan SA, Priyamvada S, Farooq N, Khan S, Khan MW and Yusufi AN. Protective effect of green tea extract on gentamicin-induced nephrotoxicity and oxidative damage in rat kidney. Pharmacological Res. 2009; 59 (4): 254-62.

123. Heinrich $M$, Chan J, Wanke $S$, Neinhuis $C$ and Simmonds MS. Local uses of Aristolochia species and content of nephrotoxic aristolochic acid 1 and 2-a global assessment based on bibliographic sources. J. Ethnopharmacol. 2009; 125 (1): 108-44.

124. Asif M. A brief study of toxic effects of some medicinal herbs on kidney. Advanced Biomedical Res. 2012; 1: 44.

125. Ferraro PM, Costanzi S, Naticchia A, Sturniolo A and Gambaro G. Low level exposure to cadmium increases the risk of chronic kidney disease: analysis of the NHANES 1999-2006. BMC Public Health 2010; 10 (1): 304.

126. Smitherman $J$ and Harber $P$. A case of mistaken identity: herbal medicine as a cause of lead toxicity. American J. Industrial Medicine 1991; 20 (6): 795-8.

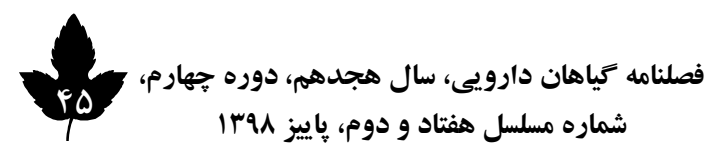




\title{
Role of Medicinal Herbs in the Development of Renal Adverse Effects: A Review Study
}

\author{
Abdollahi E (Ph.D. Student) ${ }^{1}$, Khodaparast M (Pharm.D. Student) ${ }^{2}$, Kiashi F (Ph.D. Student) ${ }^{3}$, \\ Hoormand M (Ph.D. $)^{1 *}$ \\ 1- Department of Pharmacology, Faculty of Medicine, Iran University of Medical Sciences, \\ Tehran, Iran \\ 2- Faculty of Pharmacy, Pharmaceutical Sciences Branch, Islamic Azad University \\ (IAUPS), Tehran, Iran \\ 3- Department of Pharmacognosy, Faculty of Pharmacy, Tehran University of Medical \\ Sciences, Tehran, Iran \\ *Corresponding author: Department of Pharmacology, Faculty of Medicine, Iran University \\ of Medical Sciences, Tehran, Iran \\ Tel: +98-21-86703119, Fax: +98-21-88622696 \\ Email: hoormand.m@iums.ac.ir
}

\begin{abstract}
The use of herbal medicines dates back to the beginning of the human history. Today, herbal medicines still play a significant role in the prevention and treatment of disease in many cultures and communities. There are few reports about adverse effects of herbal medicines. This is why many people around the world believe that herbal medicines can't cause adverse effects. They believe plants are safe, even if they're not efficient. This idea is wrong, regardless of how common it might be considered. Plants can be dangerous and even lethal in some cases. It is not just plant chemicals that might cause adverse effects. The role of environmental pollutants and the presence of fraud in form of alternation and adulteration in herbal preparations is another factor that might contribute to harmful effects on various organs of the body, including the kidneys. Kidneys are vital organs that filter blood, remove wastes and excrete the wastes in the urine. They are susceptible to injury because of their high exposure to different chemical substances including chemicals from the herbs. This is why studying the possible adverse effects of herbal medicines on kidney structure and function gets important. This issue highlights the role of regulatory and legislator organizations in providing up-to-date laws to help maintain a better regulation on the production and consumption of herbal products. This article reviews the findings on this case. We used papers published between 1990 and January 2018 in pubmed and google scholar databases.
\end{abstract}

Keywords: Adverse Drug Reactions, Drug adulteration, Environmental Pollutants, Herbal Medicines, Kidney 